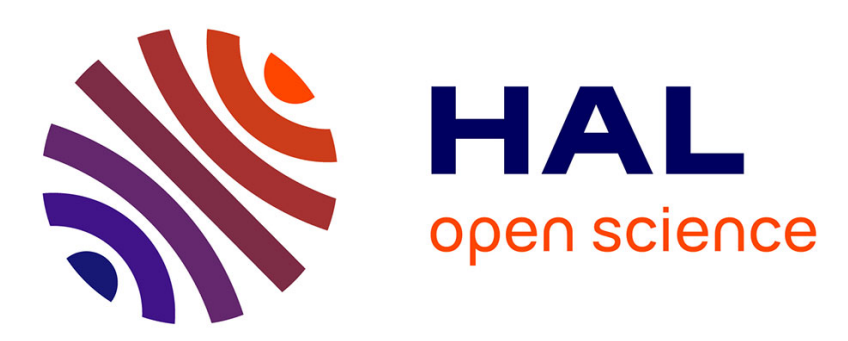

\title{
Rapid erosion of the Southern African Plateau as it climbs over a mantle superswell
}

Jean Braun, François Guillocheau, Cécile Robin, Guillaume Baby, Hielke Jelsma

\section{- To cite this version:}

Jean Braun, François Guillocheau, Cécile Robin, Guillaume Baby, Hielke Jelsma. Rapid erosion of the Southern African Plateau as it climbs over a mantle superswell. Journal of Geophysical Research, 2014, 119 (7), pp.6093-6112. 10.1002/2014JB010998 . insu-01059459

HAL Id: insu-01059459

https://hal-insu.archives-ouvertes.fr/insu-01059459

Submitted on 8 Sep 2014

HAL is a multi-disciplinary open access archive for the deposit and dissemination of scientific research documents, whether they are published or not. The documents may come from teaching and research institutions in France or abroad, or from public or private research centers.
L'archive ouverte pluridisciplinaire HAL, est destinée au dépôt et à la diffusion de documents scientifiques de niveau recherche, publiés ou non, émanant des établissements d'enseignement et de recherche français ou étrangers, des laboratoires publics ou privés. 


\section{Journal of Geophysical Research: Solid Earth}

\author{
RESEARCH ARTICLE \\ 10.1002/2014JB010998 \\ Key Points: \\ - New data support rapid denudation of \\ Southern Africa in Late Cretaceous \\ - Tilting of plateau over a source of \\ dynamic topography enhances erosion \\ - Lithology and climate also played a \\ role in the plateau denudation
}

Correspondence to:

J. Braun,

jean.braun@ujf-grenoble.fr

\section{Citation:}

Braun, J., F. Guillocheau, C. Robin, G. Baby, and H. Jelsma (2014), Rapid erosion of the Southern African Plateau as it climbs over a mantle superswell, J. Geophys. Res. Solid Earth, 119, 6093-6112, doi:10.1002/2014JB010998.

Received 30 JAN 2014

Accepted 3 JUL 2014

Accepted article online 9 JUL 2014

Published online 30 JUL 2014

\section{Rapid erosion of the Southern African Plateau as it climbs over a mantle superswell}

\author{
Jean Braun ${ }^{1}$, François Guillocheau ${ }^{2}$, Cécile Robin ${ }^{2}$, Guillaume Baby ${ }^{2}$, and Hielke Jelsma ${ }^{3}$ \\ ${ }^{1}$ Institut des Sciences de la Terre, Université Grenoble Alpes et CNRS, Grenoble, France, ${ }^{2}$ Géosciences Rennes, Université de \\ Rennes 1 et CNRS, Rennes, France, ${ }^{3}$ De Beers Exploration, Johannesburg, South Africa
}

\section{Introduction}

The Southern African craton is characterized by a large (>1000 m) topographic anomaly (Figure 1), which is often regarded as the expression of the surface upwelling caused by flow in the underlying mantle associated with the African superplume, a large low-seismic velocity zone that is imaged in most tomographic models of the mantle [Nyblade and Robinson, 1994; Gurnis et al., 2000; Nyblade and Sleep, 2003]. There is, however, debate about the timing of this uplift, and thus the age and rising rate of the superplume. The thermochronological data and numerical models of escarpment erosion and retreat [Gallagher and Brown, 1999; van der Beek et al., 2002] suggest that uplift of the plateau may predate the breakup of Gondwana resulting in a rapid and substantial base level fall around the margins of Africa at the time of rifting (between 140 and $100 \mathrm{Ma}$ ) and the subsequent retreat of the escarpment to its present-day position. The thermochronological [Brown et al., 2002; Flowers and Schoene, 2010], offshore well data [Brown et al., 1990] and sedimentary flux estimates from the Orange basin [Rouby et al., 2009] suggest that an important and rapid phase of erosion affected most of the plateau in the Late Cretaceous (around 100-60 Ma). This phase of denudation is then commonly associated with uplift of the plateau with respect to sea (base) level. A third scenario uses the arbitrary correlation between planation surfaces across the plateau and the surrounding low lying areas [Partridge and Maud, 1987] to conclude that a substantial part of the present-day topography is the product of a more recent phase of uplift (i.e., in the last $30 \mathrm{Myr}$ ) and is potentially related to the onset of uplift and rifting in the East African Rift System [Burke, 1996].

Here we present a new compilation of the terrigeneous sedimentary flux from around the Southern African Plateau that confirms the intense episode of rapid erosion around 90-80 Ma and therefore confirms the scenario of Late Cretaceous uplift of the plateau. The large volume of sediment shed from the continent in a relatively short duration (a few tens of Myr) suggests, however, that the uplift was relatively fast and that up to 1-2 km of sediment was removed from the entire surface during uplift or shortly after.

The rate of change of dynamic topography caused by a plume rising in the mantle is very low (less than $10 \mathrm{~m} / \mathrm{Myr}$ ) [Gurnis et al., 2000] and cannot, therefore, be called upon to explain the rapid rise and erosion of the plateau in 

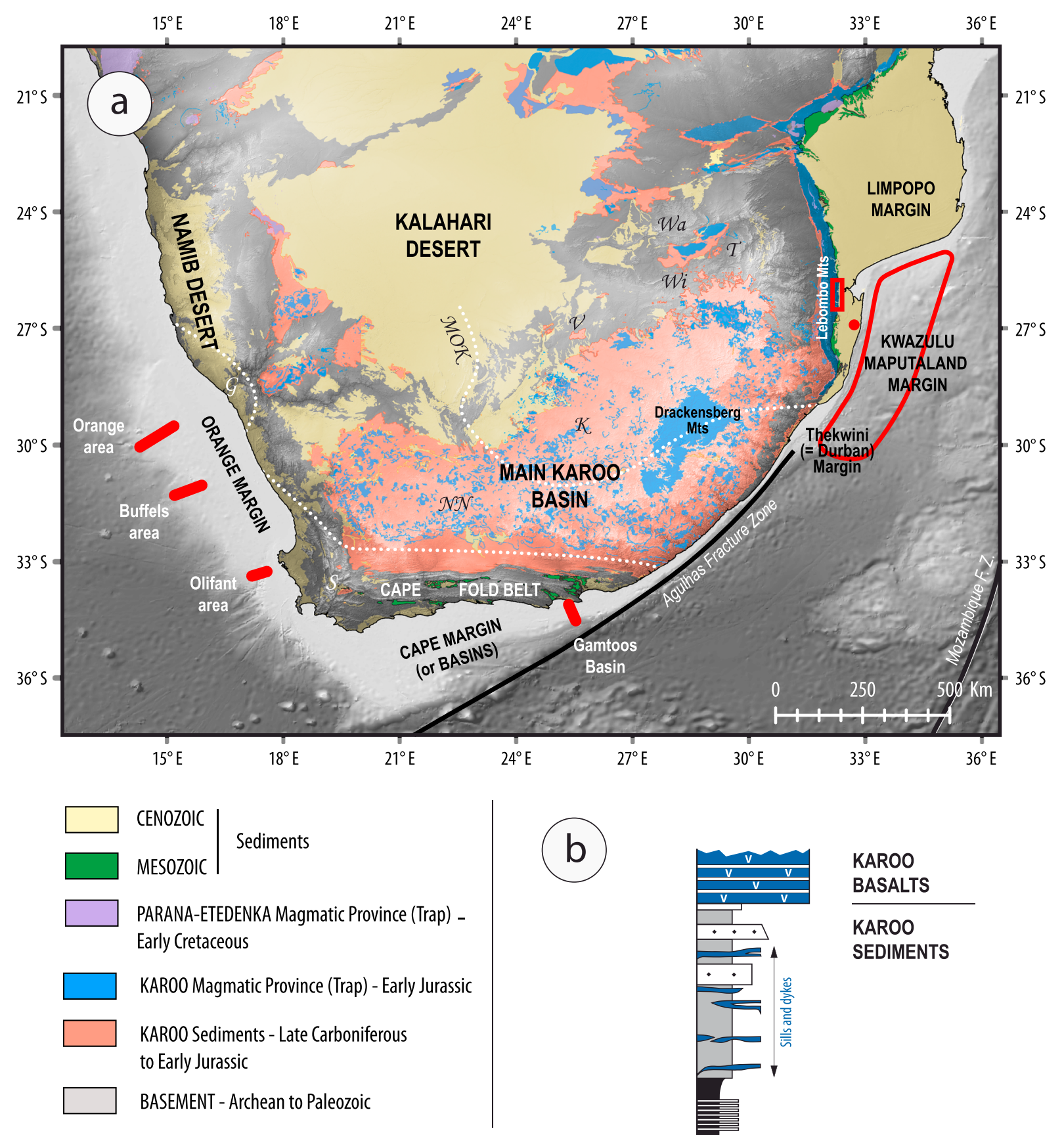

\section{ARCHEAN to PROTEROZOIC}

Wa: Waterberg Basin $\quad \mathcal{T}$ : Transvaal Basin
Wi: Witwatersrand Basin $\quad \mathcal{V}$ : Ventersdorp Basin
K: Kaapvaal Craton
MOK: Magondi-Okwa-Kheis Belt
$\mathcal{N} \mathcal{N}$ : Namaqua-Natal Belt
S: Saldania Belt

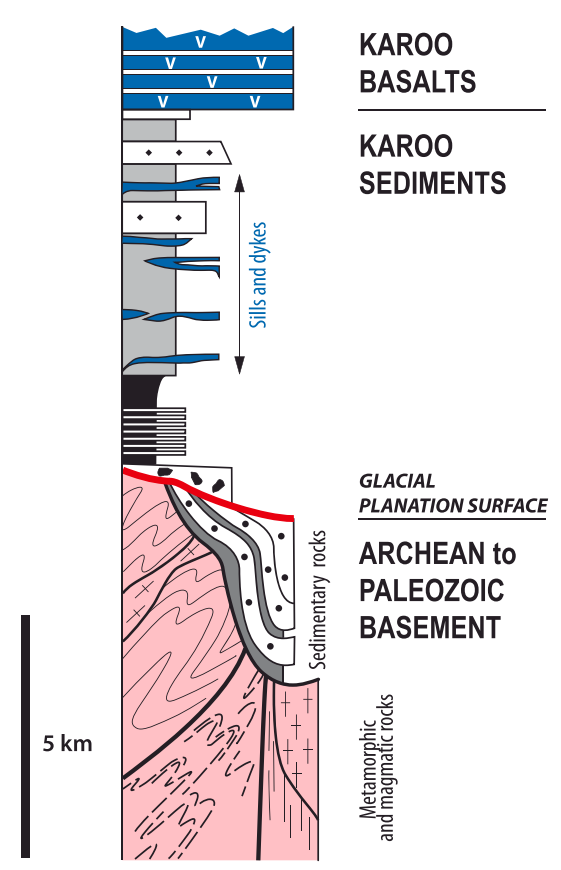

Figure 1. (a) Main geological elements constitutive of the uppermost continental crust of the Southern African Plateau superimposed on the topography (Shuttle Radar Topography Mission 90) and location of the seismic data, wells, and outcrops hereafter used (Figure 2). (b) Synthetic lithological succession from the Archean-Paleozoic basement to the Early Jurassic Karoo floods basalts. 
the Late Cretaceous. This led some authors [Gallagher and Brown, 1999; Bell et al., 2003] to suggest a lithospheric instability, potentially resulting from Gondwana breakup, as the cause for the rapid rise of the plateau. The geochemical signature of xenoliths from kimberlite pipes suggests a major lithospheric-scale Mesozoic thermal or metasomatic event that is consistent with a major lithospheric delamination event [Bell et al., 2003].

As we will demonstrate later, the northeastward motion of Africa over a relatively fixed and already buoyant mantle can also easily explain the rapid uplift suggested by the sedimentary flux data. There remains to explain, however, how up to $1-2 \mathrm{~km}$ of rocks have been removed from a large (2000 km wide) plateau in a few tens of millions of years (and thus a mean erosion rate of $100 \mathrm{~m} / \mathrm{Myr}$ sustained over a period of a few tens of million years). There is clear evidence that present-day plateau surfaces, such as in the Tibetan plateau, the Altiplano, or the Southern African Plateau, erode at very low rate (less than $10 \mathrm{~m} / \mathrm{Myr}$ ), mostly because they are characterized by very low slopes and low precipitation rates. Plateaus erode by river incision along their margins, which are characterized by very steep slopes and where orographic control on precipitation focuses rainfall. Removal of a substantial thickness of rocks from the entire surface of a plateau therefore requires the propagation of knick points over thousands of kilometers, a process that is likely to take hundreds of millions of years.

The episode of rapid exhumation over the top of the plateau may therefore indicate that the climate was much wetter in the Late Cretaceous than it is today, or that, contrary to the Tibetan plateau or the Altiplano, the surface of the Southern African Plateau was characterized by high relief. As we will show later, there is evidence that the climate of Southern Africa was slightly wetter 80-90 Myr ago, but it is difficult to estimate whether this is sufficient to justify a tenfold to a twentyfold increase in erosion rate. We will present here a new compilation on paleoprecipitation indicators to demonstrate that only the margins of the plateau have experienced enhanced precipitation rate in the mid- to Late Cretaceous. There is also strong evidence that the plateau surface was covered by a 1-2 km thick sequence of marine sediments topped by a layer of Karoo volcanic rocks (that erupted at around $180 \mathrm{Ma}$ ), which suggests that the plateau surface was relatively flat.

Here we explore the possibility that the motion of Africa over a fixed source of upward mantle flow explain not only its relatively high rate of uplift but also the rate at which it has been eroded. Braun et al. [2013] have shown that, despite the relatively low slopes that it creates, the motion of a continent over a fixed source of dynamic topography may lead to substantial, i.e., kilometer scale, and rapid surface erosion, through continental-scale drainage reorganization. We demonstrate that it is the tilt experienced by the continent as it climbs over the dynamic topography high that is responsible for the rapid pulse of erosion. Our approach is based on a careful interpretation of the existing geological record and the use of a very efficient numerical model, which can be used to quantify the effects of a large-scale, low-amplitude tilt of a continent. We will first review the data pertaining to the uplift of Southern Africa during the Upper Cretaceous, its paleoclimate, and the sedimentary record of the surrounding margins. We will then briefly present the numerical model and describe a series of numerical experiments designed to find which among a wide range of setups and uplift scenarios fit best the observations.

\section{Geological Constraints on Late Cretaceous Erosion}

The Southern African Plateau is a westward tilted plateau, extended over two third of the Southern African subcontinent at an average elevation of $1000 \mathrm{~m}$ [Nyblade and Sleep, 2003, Figure 1a]. The surrounding escarpment is highest along the Drakensberg Mountains (SE) and lowest along the Orange Delta (W). The Southern African Plateau is bounded by two margins, a divergent passive margin on the Atlantic Ocean side with two main presentday feeding rivers, the Orange and the Olifant Rivers and a transform margin on the Indian Ocean side.

\subsection{Evidence for a Strong Lithological Contrast Between Karoo Sedimentary and Volcanic Rocks and the Underlying Basement}

The continental crust of the Southern African Plateau (Figures $1 \mathrm{a}$ and $1 \mathrm{~b}$ ) comprises a large Archean nucleus, here referred to as the Southern African craton, which is an amalgamation of the Zimbabwe and Kaapvaal cratons linked across the intervening Limpopo Belt. The southern part of the craton is in parts overlain by Mesoarchean and Paleoproterozoic sedimentary and volcanic basins (Witwatersrand, Ventersdorp, Transvaal, and Waterberg). The craton is surrounded by Proterozoic terranes that include the Paleoproterozoic Magondi-Okwa-Kheis Belt, the Mesoproterozoic Namaqua-Natal Belt, and the Neoproterozoic Gariep and 
a)

ORANGE MARGIN: Orange area

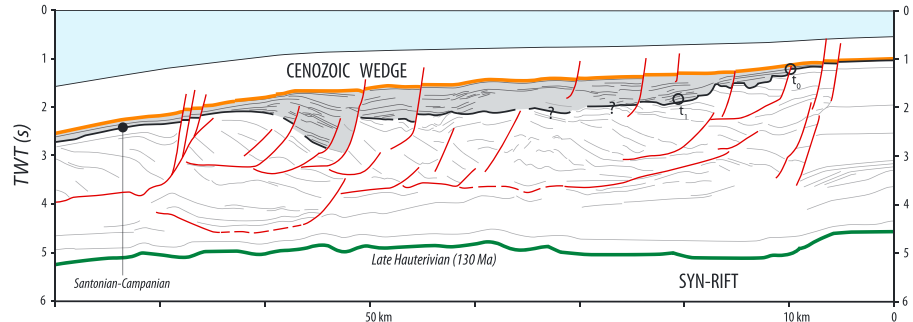

ORANGE MARGIN: Buffels area

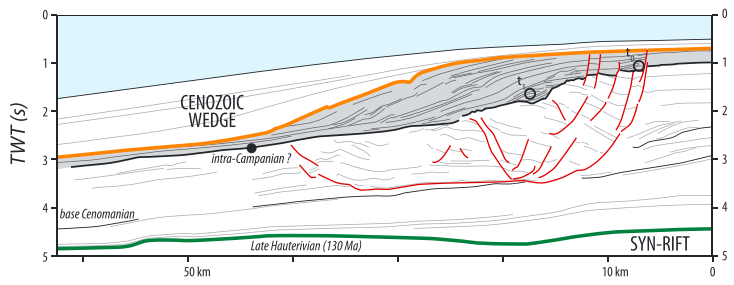

ORANGE MARGIN: Olifant area

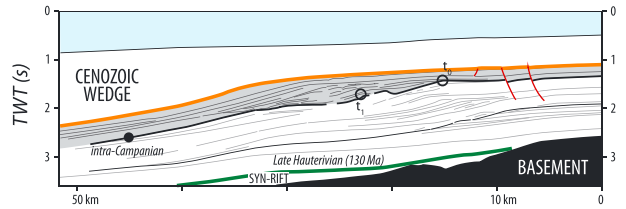

CAPE MARGIN: Gamtoos Basin

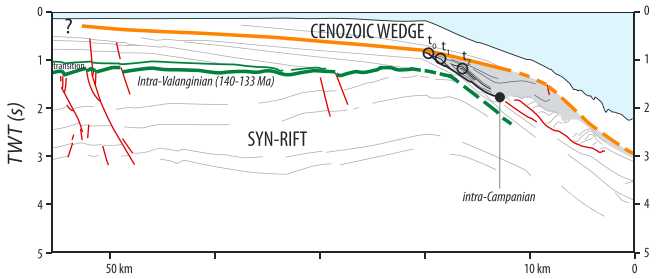

- CRETACEOUS - CENOZOIC BOUNDARY TRANSITION RIFT TO POST-RIET

$\backslash$ FAULTS

LOWSTAND SYSTEM TRACT (Forced regressive + Lowstan

$\begin{array}{lr}\mathrm{Q}^{\prime} & \text { SHORELINE } \\ \text { (Offlap break) }\end{array}$

b)

\begin{tabular}{|c|c|}
\hline ONSHORE OUTCROPS \\
MAPUT'ALAND - Mozambique
\end{tabular} \begin{tabular}{c}
$\begin{array}{c}\text { ONSHORE SUBSURFACE - Coredrills } \\
\text { KWHAZUL } U \text { - Mozambique border }\end{array}$ \\
\hline
\end{tabular}

OFFSHORE SUBSURFACE - Seismic MAPUTA $A$ AND - MOZambíqu

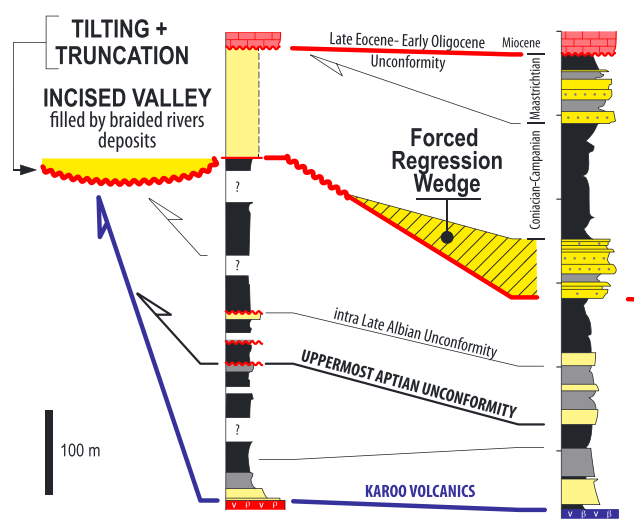
KWAZULU - 'MAPUT'ALAND deep Margin

UPPERMOST CENOMANIAN

EARLY TURONIAN

(95 - $90 \mathrm{Ma}$ )

UNCONFORMITY

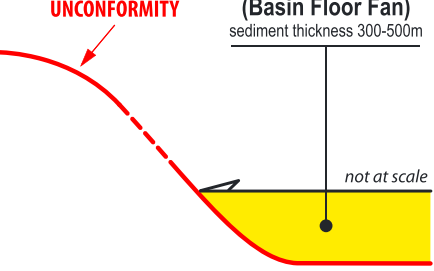


Saldania Belts. This basement is subsided during Paleozoic and Early Mesozoic times, with the growth of two main basins [Tankard et al., 2009]: (1) the Cape Basin (Ordovician to Devonian) [Shone and Booth, 2005], mainly limited to the southern part of present-day South Africa, and (2) the Karoo Basin (Late Carboniferous to Early Jurassic), covering most of South Africa. The transition between the two basins is marked by the Late Devonian-Early Permian Gondwana glaciation, a major climatic event in Southern Africa. The Karoo Basin is contemporaneous of the growth of the Cape Fold Belt [Johnson et al., 1996] and is considered as a foreland basin [Catuneanu et al., 1998] or as the result of lithospheric deflection driven by mantle flow associated with the distant southern subduction [Pysklywec and Mitrovica, 1999]. It is filled with sedimentary rocks deposited in a deep subaqueous environment evolving upward to more coarse-grained continental sediments. At the time of deposition of Early Jurassic eolian sediments, the basin subsidence pattern suggests that it had ceased to grow as a foreland basin. This succession is sharply overlain by the basalts of the Karoo Traps of Early Jurassic age (184-179.5 Ma) [see Jourdan et al., 2008]. A dense network of dolerites sills and dykes is coeval or a little younger than the basalts and rhyolites erupted on the southeastern side of the present-day plateau, along the future Lebombo Mountains (see Melluso et al. [2008] for the last review on this subject). After this major volcanic event, Southern Africa stopped subsiding, although in Zimbabwe some Upper Jurassic thin continental "red beds" are preserved [Cooper, 1988].

Lithologically, the Southern African Plateau is thus composed of the following (Figure 1b):

1. a basement of Archean to Paleozoic is mainly metamorphic and magmatic rocks (granites), overlain by competent sedimentary basins (see above);

2. a 3 to $9 \mathrm{~km}$ of Karoo siliciclastic sedimentary rocks, broadly ranging from siltstones at the base to sandstones at the top (armed by Karoo dolerites), i.e., going from softer to harder but much less resistant than the underlying basement; and

3. Karoo basalts, which have a maximum preserved thickness of $1.7 \mathrm{~km}$ in the Drakensberg area [Marsh et al., 1997]. Although these mafic rocks are intrinsically stronger than the sedimentary sequence they overlay, they are known to be very prone to rapid and efficient weathering [Dessert et al., 2003], and therefore of a mechanical resistance to erosion similar to the siliciclastic rocks. It is possible, however, that part of this volcanic cover was removed in the Early Cretaceous, as evidenced by the lack of basalt xenoliths in kimberlites that erupted since $90 \mathrm{Ma}$ [Hanson et al., 2009].

\subsection{Late Cretaceous Main Uplift and East to West Migration}

\subsubsection{Stratigraphic Characterization of Uplift}

The uplift of a plateau can be dated and measured based on the stratigraphic record of the surrounding margins. This measure is based on a sequence stratigraphic analysis of seismic lines calibrated in age and lithology by well data (here petroleum wells) or by outcrops. The basic principle is quite simple. The shoreline migration through time [Posamentier et al., 1988] is a function of subsidence/uplift driven by lithospheric deformation and/or thermal contraction, isostasy, as well as mantle flow (we will call this the "tectonic" forcing), sea level variations (eustasy), and the sediment flux (siliciclastic supply and in situ production, e.g., carbonates, evaporites,...). Only tectonic forcing and sea level variations generate vertical movements of the shoreline and thus create, or remove, in submarine domains, accommodation space [Posamentier et al., 1988] that can be filled by sediments. In our case, uplift of the margin will induce a downward migration of the shoreline (called a forced regression in the sequence stratigraphic nomenclature) [Posamentier et al., 1992], as a eustatic sea level fall would do, with upstream river incision (formation of incised valleys) and highsediment supply in the deep-sea plain (formation of basin floor fans). The next step is to discriminate the

Figure 2. Stratigraphic data (location on Figure 1) supporting a major uplift during Late Cretaceous age, earlier (uppermost Cenomanian, 90-95 Ma) in the east and later ("Campanian," 85-70 Ma) in the west. (a) Line drawing of four seismic lines with the Late Cretaceous forced regression wedges and the shoreline trajectory (offlap-break migration). The amplitude of the relative sea level fall (accommodation space removal) during "Campania" is between 0,3 s (Two-Way Travel Time (TWTT)-Gamtoos and Olifant) and 0,6 s (TWTT-Orange and Buffels), which means, using $P$ wave velocities of 2000 to $2500 \mathrm{~m} / \mathrm{s}$, local uplift ranges between 300-375 m and 600-750 m. Orange area, data of Compagnie Générale de Géophysique (CGG) Veritas published by de Vera et al. [2010] and available on the Virtual Seismic Atlas (www.seismicatlas.org)-Buffels and Olifant areas, seismic data of SOEKOR (now PetroSA) published by Brown et al. [1995]-Gamtoos Basin, seismic data by courtesy of PASA (South African Petroleum Agency). (b) Correlation between outcrops, wells, and seismic data along the Kwazulu-Maputaland Margin showing a major accommodation space removal (relative sea level fall) during uppermost Cenomanian-Early Turonian (90-95 Ma). Well data by courtesy of PASA. 
tectonic forcing from the eustatic component in a downward migration of the shoreline. Three conditions can be considered where the shoreline migration is likely to be a direct measure of uplift:

1. Based on published eustatic charts [Haq et al., 1987; Miller et al., 2005], which can sometimes be contradictory, the studied time interval does not correspond to a period of sea level fall.

2. The amplitude of the downward migration of the shoreline is larger than the maximum rate of sea level fall accepted for greenhouse or icehouse periods, i.e., around $100 \mathrm{~m}$ of sea level fall over a 1 Ma period and around $150 \mathrm{~m}$ for a duration of $100 \mathrm{Ka}$, respectively.

3. For any given time interval, noticeable spatial variations in relative sea level fall are observed, which must therefore be related to tectonic forcing [Robin et al., 1998] as eustasy is, by definition, a function of time only, not space.

2.2.2. Timing of the Uplift-East to West Migration

Four subbasins were studied (Figures 2a and 2b): the Kwazulu-Maputaland marginal basin, the offshore Gamtoos Basin, the southern Atlantic margin offshore Cape Town (Olifant Delta), and the Orange Delta Margin. All of them show evidence of forced regression wedges (or forced regressive units) with downward migration of the shoreline and river incision during Upper Cretaceous time, with an amplitude of accommodation space removal (relative sea level fall) higher than $150 \mathrm{~m}$. The exact age of this uplift is still unknown because of biostratigraphic uncertainties, but these positive vertical movements occurred between the uppermost Santonian [de Vera et al., 2010] and the Late Campanian [Brown et al., 1995], i.e., between 85 and 70 Ma. This uplift, accompanied by tilting of the margin and/or increase of the siliclastic sediment supply, is probably responsible the large slumps observed along the northern Orange Margin (Figure 2a-Orange and Buffels areas).

The Kwazulu-Maputaland margin was uplifted at the end of the Cenomanian (around 95-90 Ma). This uplift (Figure 2b) was coeval with a major tilting and erosion (truncation) of the upstream part of the margin, river incision, and the growth of a deep-sea fan (basin floor fan) fed northward and running parallel to the Agulhas and Mozambique Fracture Zones. The three other domains (Figure 2a) show well-defined forced regression wedges around Campanian times (85-70 Ma). This implies a westward migration of the uplift, with a first uplift of the eastern domain (Thekwini and Kwazulu-Maputaland margins) around 90-95 Ma and uplift in the west around 85-70 Ma. 2.2.3. Position of Africa With Respect to a Fixed Mantle Source of Dynamic Uplift This asynchronism in the uplift signal suggests that the uplift could be related to the motion of Africa with respect to the underlying mantle. In Figure 3a, we show a reconstruction of the position of the African continent in the African superplume (fixed hot spot) frame of reference [Torsvik et al., 2010; Torsvik and Cocks, 2013]. This reconstruction clearly shows that the continent moved in an eastward fashion from at least $140 \mathrm{Ma}$ to present-day and was entirely positioned over it by about $70 \mathrm{Ma}$. This suggests that, if the superplume was responsible for substantial surface dynamic topography, the continent must have experienced a progressive uplift from east to west and thus a tilt. This tilt could, in turn, have generated a major drainage reorganization, which would be consistent with the asymmetry in the sedimentary flux between the western margin and its relatively starved eastern counterpart. Note that the position and distribution of upward flow within the African superplume is still open to much debate [Simmons et al., 2007]. Our main argument here is that the continent has moved toward and over it in the Late Cretaceous.

\subsubsection{Relation With the Ages of the Kimberlites}

Figure $3 \mathrm{~b}$ shows the distribution of age-dated kimberlites (circles) and related rocks (stars) across Southern Africa grouped according to age (based on Jelsma et al. [2004, 2009]), illustrating progressive age variation of kimberlite magmatism. Three periods can be defined (1) from 210 to $105 \mathrm{Ma}$ with a migration from east to the central part of South Africa, (2) from 105 to $80 \mathrm{Ma}$ with a widespread distribution across central South Africa and Botswana with no distinct age progression, and (3) from 80 to $48 \mathrm{Ma}$ with again a westward migration from the central part of South Africa to the coastal region. This age progression with older ages in the east suggests source migration from east to west and is, potentially, in accordance with the northeastward motion of Africa over a stationary mantle, if a link exists between kimberlite eruptions and the underlying mantle structure/dynamics as suggested by Torsvik et al. [2010].

\subsection{Siliciclastic Sedimentary Flux Along the Margins of Southern Africa}

Siliciclastics sediment fluxes were measured using seismic lines and biostratigraphically dated wells according to the technique published by Guillocheau et al. [2012]. The volume of sediments, for each time interval, was measured by interpolation between cross sections and corrected for in situ carbonate production and porosity to obtain siliciclastic solid volumes. 

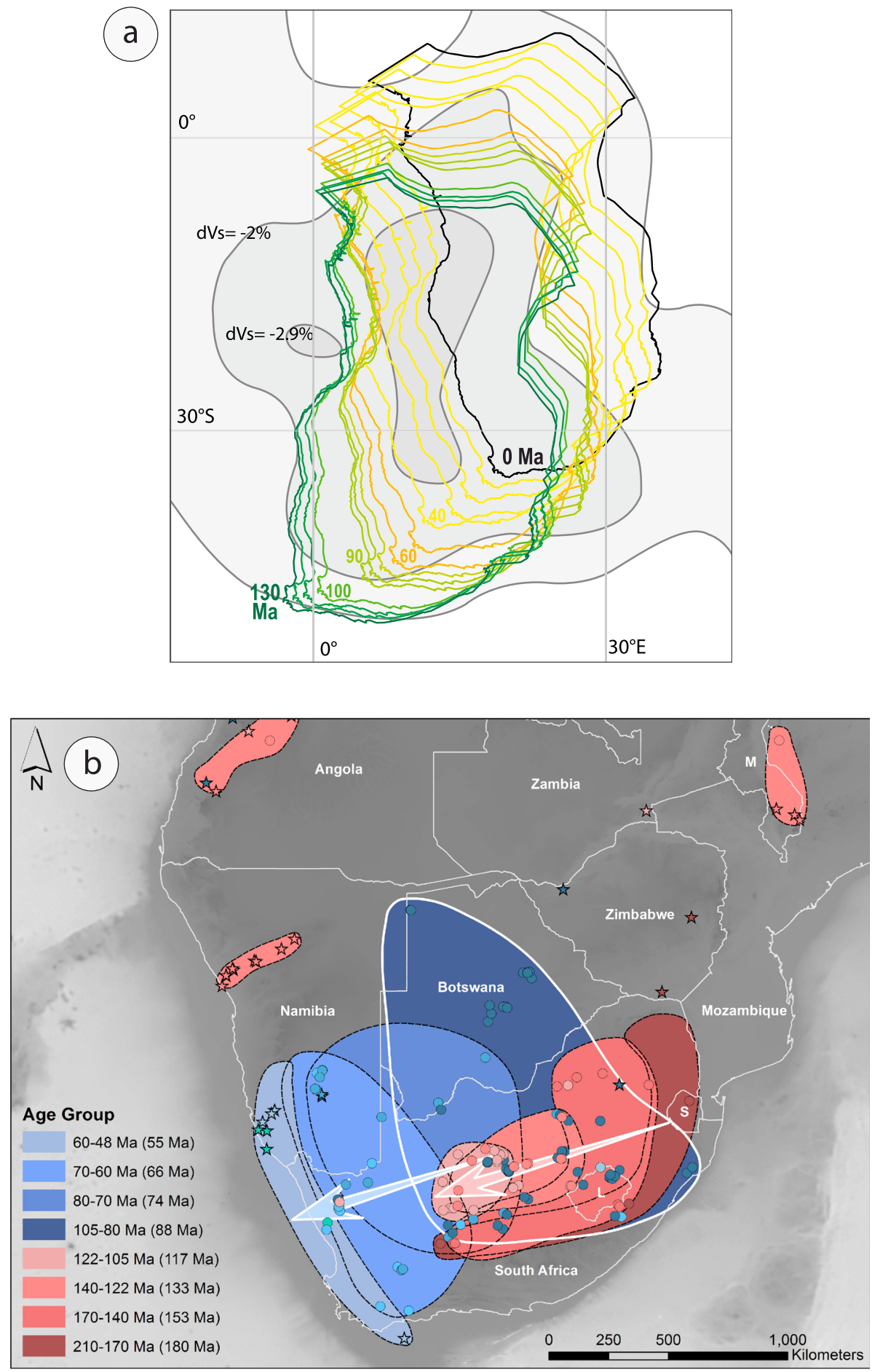

Figure 3. (a) Relationship between the migration of Africa over the past $130 \mathrm{Myr}$ (color lines from Gplates software by Qin et al. [2012]) and a possible mantle upwelling, drawn from the present-day position of the African superplume for reference (grey shaded contours based on Torsvik et al. [2010] and Torsvik and Cocks [2013]). (b) Successive locations of kimberlites from $210 \mathrm{Ma}$ (uppermost Triassic) to $28 \mathrm{Ma}$ (Oligocene) in Southern Africa [Jelsma et al., 2004], showing an east-west migration of their location through time, potentially related to the movement of the African plate over the superplume. 


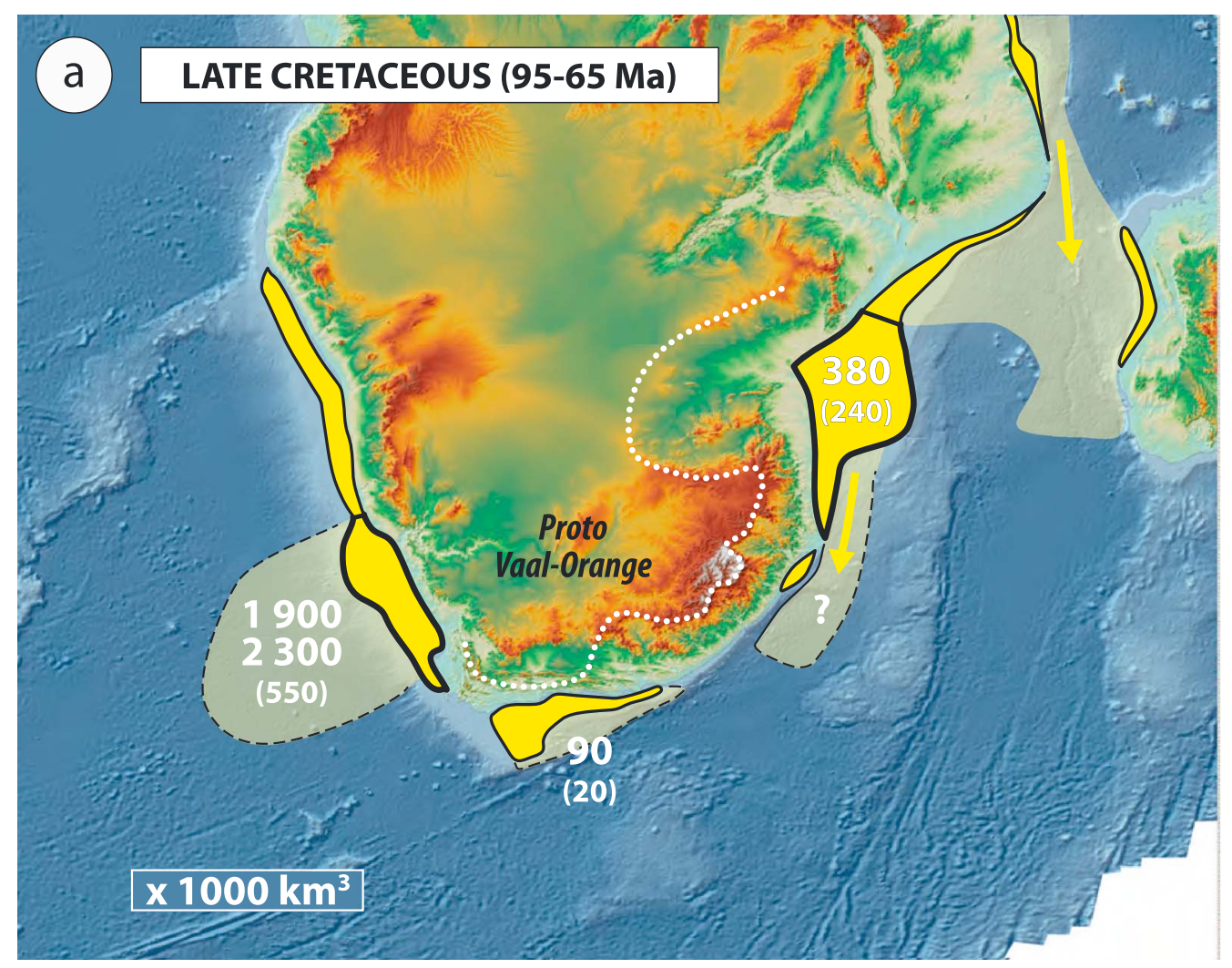

(b) ATLANTIC MARGIN SEDIMENT VOLUME (Walvis Ridge - Cape of Good Hope)

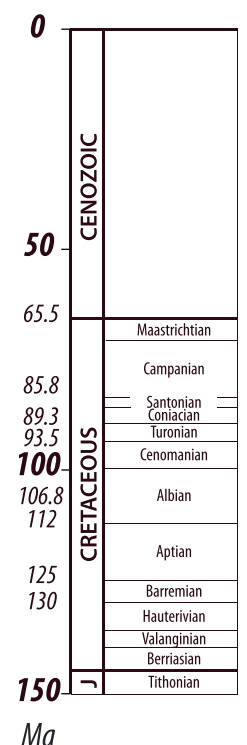

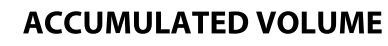

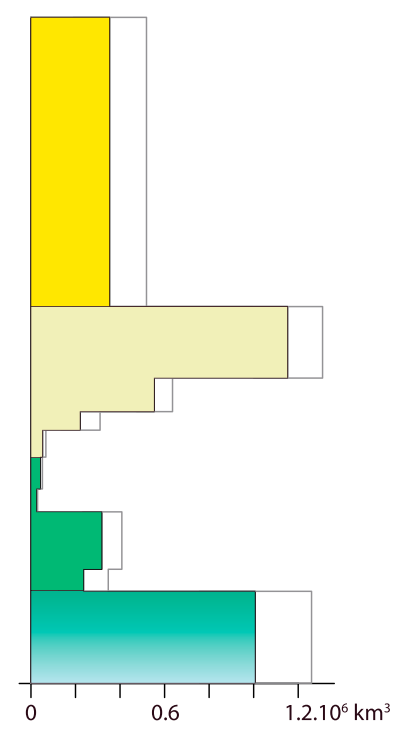

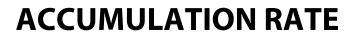

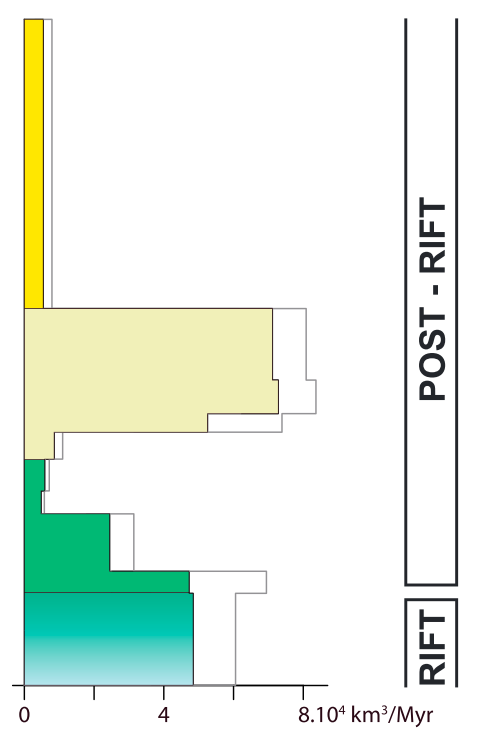

Figure 4. Sedimentary fluxes around the Southern African Plateau since Cretaceous times. (a) Location of the main sediment feeders (deltas and deep-sea fans) and amount of deposited sediments $\left(10^{3} \mathrm{~km}^{3}\right)$ for the Late Cretaceous and Cenozoic (numbers between parentheses). (b) Evolution of the deposited sediment volumes along the Orange Margin since Lower Cretaceous (modified from Guillocheau et al. [2012]). 
These measurements were made at two different temporal resolutions according to the biostratigraphic data available: we used two time intervals (the Late Cretaceous and the Cenozoic) for the area surrounding the entire plateau (Figure 4a), and much smaller intervals of a few million years for the Atlantic Ocean Margins (Figure 4b). Those measurements were based on seismic lines and wells for the Atlantic [Brown et al., 1995], Thekwini (Durban), Kwazulu-Maputaland and Limpopo margins, and on published data [Tinker et al., 2008] for the Cape margins, where the Cretaceous-Paleogene sedimentary record is incomplete, because of the erosion by Neogene oceanic currents [Uenzelmann-Neben et al., 2007].

The siliciclastic sediment flux (Figure $4 \mathrm{~b}$ ) shows a sharp rate increase at the end of the Cenomanian, around 90-95 Ma. This event occurred at the same time around the Southern Africa Plateau, from the Atlantic to the Indian margins. The integrated measurement of the siliciclastic sediment volumes (Figure $4 \mathrm{a}$ ) indicates a major change between the Late Cretaceous and the Cenozoic. Along the Orange-Walvis Margin, the deposited volume is between 1900 and $2300 \times 10^{3} \mathrm{~km}^{3}$ for the Late Cretaceous and only $550 \times 10^{3} \mathrm{~km}^{3}$ for the Cenozoic. For the Cape Basins (truncated by the Neogene oceanic currents), the Upper Cretaceous volume is $90 \times 10^{3} \mathrm{~km}^{3}$ and the Cenozoic volume is $20 \times 10^{3} \mathrm{~km}^{3}$. On the Indian Ocean side, a major drainage reorganization occurred during Cenozoic times, with the birth of the present-day Limpopo and Zambezi Rivers around the Eocene-Oligocene boundary (based on the age of the beginning of the Limpopo and Zambezi Deltas by Salman and Abdula [1995]). On the present-day Limpopo onshore flat (including the Natal Valley) and in the offshore delta, the minimum volume of siliciclastic sediments is $380 \times 10^{3} \mathrm{~km}^{3}$ for the Upper Cretaceous and $240 \times 10^{3} \mathrm{~km}^{3}$ for the Cenozoic.

Note that the earlier pulse of sedimentation clearly evidenced along the Atlantic margin (Figure $4 \mathrm{~b}$ ) is related to the rifting phase and the formation of the margin, which either uplifted the flanks of the continent or caused a base level drop, which, in turn, drove the rapid erosion of the continent edges [van der Beek et al., 2002; Brown et al., 2002]. This uplift did not cause much erosion of the interior of the plateau as evidenced by low-temperature thermochronological data [Flowers and Schoene, 2010].

\subsection{Paleoprecipitations During Cretaceous and Cenozoic Times}

No synthetic study exists on the paleoclimate evolution of Southern Africa, except for the Cenozoic [Tyson and Partridge, 2000]. Here we compiled all available data with the purpose of characterizing any precipitation change through Cretaceous and Cenozoic times. This study is mainly based on paleoflora record [Bamford, 2000], well dated by micropaleontology (foraminifers), palynology (spores and pollens), or vertebrate paleontology (mainly mammals). The precipitation recorders were mainly the association of plants (including trees), based on fossilized woods, spores, and pollens, characteristic of arid, semiarid, humid or very humid settings or other key indicators such as the type of plant association (bush, savanna, and coastal forest). Seasonality was estimated from the growth rings of the wood or, more rarely, the shape of the leaves or the type of stomates on well-preserved cuticules [Gomez et al., 2002]. We also used the occurrence of eolian deposits dated for the Neogene by ostrich eggs [Senut and Pickford, 1995]. Because of poor dating, paleosoils were not used. The data are summarized in Figure 5 for two regions characterized by different elevations. The first and most complete record corresponds to the areas near the margins (the past coastal plains) and the second one to the interior of the plateau.

The base Cretaceous (140-130 Ma) is arid to semiarid with the deposition of eolian desert sediments, prior the Parana Flood Basalts, at the end of the South Atlantic (Austral segment) rifting (Twyfelfontein sandstones) [Jerram et al., 1999; Wanke et al., 2000]. The transition from a semiarid to a very humid setting was probably sharp, within the Barremian. From 130 to around $90 \mathrm{Ma}$, the climate was progressively drier [Sandersen, 2006], with a paroxysm of semiaridity around the Turonian-Coniacian boundary. On the plateau, lake sediments preserved in kimberlites craters (Orapa, Botswana) [Rayner et al., 1997] indicate a seasonally temperate milder humid environment. Along the coastal plain, the return toward very humid conditions was quite fast. Very humid conditions prevailed since $85 \mathrm{Ma}$ (intra-Santonian). From 75 to $55 \mathrm{Ma}$ (uppermost CretaceousPaleocene), no data are available, except on the plateau where the flora of a crater lake (Arnot Pipe, Banke) [Smith, 1986, 1988] indicates a dry open forest in warm temperate conditions for the Maastrichtianlowermost Paleocene (70-65 Ma). The Eocene (55-40 Ma) was very humid. The upper Eocene (40-35 Ma) is a transitional period with drier conditions (semiarid in the Sperrgebiet, southern Namibia) [Bamford, 2000], announcing the major global-scale climate change of the Eocene-Oligocene boundary. Unfortunately, no data are available for the Oligocene and lowermost Miocene (34-20 Ma), beginning of the Ice House period. 


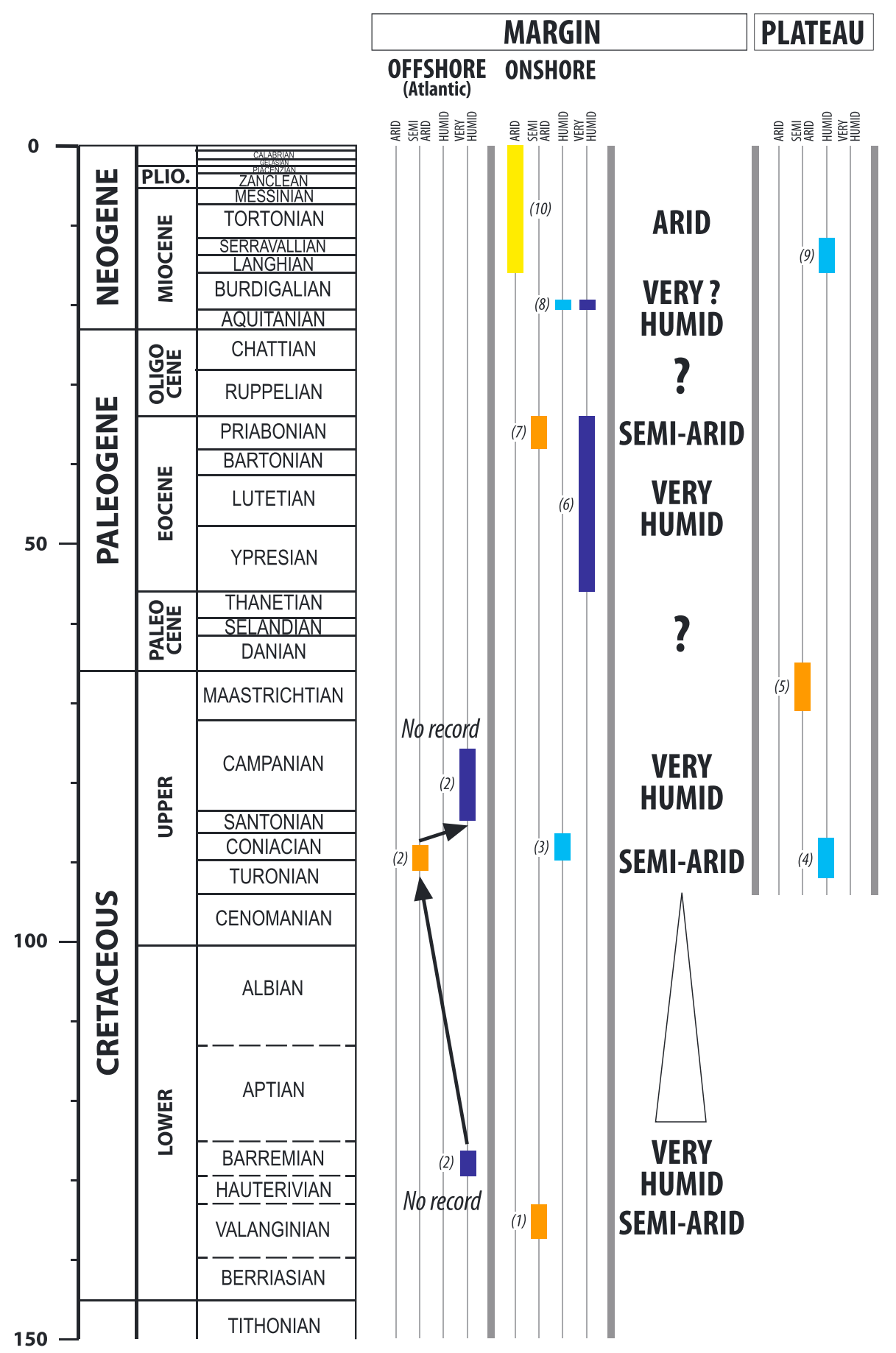

Figure 5. Precipitation change chart for the Cretaceous and Cenozoic, mainly based on paleoflora data (see text). Four categories are defined: very humid (similar to present-day Gabon-North Congo conditions), humid, semiarid, and arid (desert similar to the Namib Desert). Data: (1) Gomez et al. [2002], (2) Sandersen [2006], (3) Bamford and Stevenson [2002], (4) Rayner et al. [1997], (5) Smith [1986, 1988], (6) de Villiers [1999], (7) Bamford [2000], (8) Roberts et al. [2013], (9) Bamford [2000]-Bamford and de Wit [1993], and (10) Pickford and Senut [1999].

Along the coastal plain, the Burdigalian (20-16 Ma) was again (very?) humid, before a major (still acting) dry event starting around $15 \mathrm{Ma}$ at time of first eolian sediments deposition in the Namib Desert [Pickford and Senut, 1999; Ségalen et al., 2006]. Uppermost Miocene to present-day (8-0 Ma) Africa-scale increase of humidity (7.5-7 and 5-3.5 Ma, from Bonnefille [2010]) is moderately recorded in Southern Africa. 
Table 1. Model Parameter Values

\begin{tabular}{lcc} 
Symbol & Parameter Name (and Units) & Reference Value \\
\hline$K$ & reference erodibility (m ${ }^{1-2 \mathrm{~m} / \mathrm{yr})}$ & $1 \times 10^{-6}$ \\
$m$ & area exponent & 0.4 \\
$n$ & slope exponent & 1 \\
$L_{x}, L_{y}$ & dimension of the experiment (m) & $2 \times 10^{6}$ \\
$\Delta x, \Delta y$ & spatial resolution of the model (m) & $1 \times 10^{3}$ \\
$\Delta t$ & time step length (year) & $1 \times 10^{5}$ \\
$T_{e}$ & Effective Elastic Thickness (m) & $20 \times 10^{3}$ \\
$E$ & Young modulus (Pa) & $1 \times 10^{11}$ \\
$v$ & Poisson's ratio & 0.25 \\
$\rho_{s}$ & surface (crustal) density (kg/m $\left.{ }^{3}\right)$ & 2800 \\
$\rho_{a}$ & asthenospheric density (kg/m $\left.\mathrm{m}^{3}\right)$ & 3200 \\
$T$ & duration of uplift/tilt phase $(\mathrm{year})$ & $30 \times 10^{6}$ \\
\hline
\end{tabular}

2.5. Summary: Topographic, Erosional, and Climatic Evolution of the Southern African Plateau During Upper Cretaceous Times

The Southern African Plateau experienced a two steps uplift during Upper Cretaceous times. The first one, around 95-90 Ma, is limited to the eastern part of the presentday plateau. This uplift generated an active erosion of the plateau in a semiarid to humid setting (with a sharp transition at $80 \mathrm{Ma}$ from dryer to wet). The products of this erosion are distributed all around the plateau since 95-90 Ma, probably in response

to a proto-Vaal-Orange drainage system. The second uplift phase, at 75-70 $\mathrm{Ma}$, is mainly recorded on the western side, whereas erosion stopped between 70-75 and 65-60 Ma in the west and center of the plateau, respectively, as indicated by the preservation of kimberlite craters filled with lacustrine sediments (the Stompoor Pipes [Smith, 1986] and the Arnot Pipes [Scholtz, 1985a, 1985b]).

\section{Model Description}

Continental surface erosion is controlled by the rate at which rivers incise into bedrock and transport the resulting sediments. Fluvial incision is commonly parameterized by the stream power law [Howard and Kerby, 1983], which states that erosion (incision) rate, $\mathrm{d} h / \mathrm{d} t$, is function of local slope, $S=\mathrm{d} h / \mathrm{d} x$, and drainage area, $A$, which is taken as a proxy for discharge, under the assumption that net precipitation is spatially uniform [Howard and Kerby, 1983; Whipple and Tucker, 1999]:

$$
e=\frac{\partial h}{\partial t}=K A^{m} S^{n}=K A^{m}\left(\frac{\partial h}{\partial x}\right)^{n}
$$

In this relationship, $K, m$, and $n$, are commonly assumed to be constant in space and time and represent the dependency of erosion rate on climate, i.e., precipitation [Whipple and Tucker, 1999] and precipitation variability [Lague and Hovius, 2005], and lithology [Whipple and Tucker, 1999]. Their values are poorly constrained, except for the ratio $\mathrm{m} / \mathrm{h}$, which is known to be close to $0.4-0.5$, based on the concavity of river profiles in actively uplifting areas [Whipple, 2004].

We have solved this equation using a first-order implicit finite difference scheme [Braun and Willett, 2012] over a $2000 \mathrm{~km}$ by $2000 \mathrm{~km}$ area, which we discretized at $1 \mathrm{~km}$ resolution. Time integration is performed using 1000 times steps of 100 kyr duration. We tested that the solution does not depend on the grid spacing or time step by increasing and decreasing both values. The initial topography is flat and at sea level. We imposed that all four boundaries remain at sea level, i.e., $h=0$. The lithological contrast between the Precambrian basement/Karoo sedimentary rocks and the overlying volcanic rocks is included in the model by varying the coefficient $K$ with depth. We will assume that the first $1 \mathrm{~km}$ of rocks (the Karoo volcanic rocks) is characterized by a value of $K 10$ times larger than that corresponding to the underlying lithologies.

This surface processes model is coupled to a thin elastic plate model representing the flexural isostatic response of the lithosphere to both erosional unloading and vertical stresses originating in the underlying mantle [see Braun et al., 2013]. Values for the flexural parameters and surface and asthenospheric densities are given in Table 1.

As stated earlier, we will assume that erosion of the Southern African Plateau is related to a phase of uplift associated with the passage of Southern Africa over a source of upward mantle flow, generating dynamic topography [Gurnis et al., 2000]. We have represented this upward mantle flow by imposing a vertical stress at the base of the thin elastic plate representing the lithosphere, which results in uplift of the surface, the creation of relief (and thus slope), and subsequent erosion by fluvial processes, as described above. We consider two scenarios (see Figure 6): one in which the vertical stress resulting from mantle flow is spatially uniform beneath the Southern African craton (we will refer to this scenario as the "no-tilt case"; Figure 6a), 
a) No tilt scenario
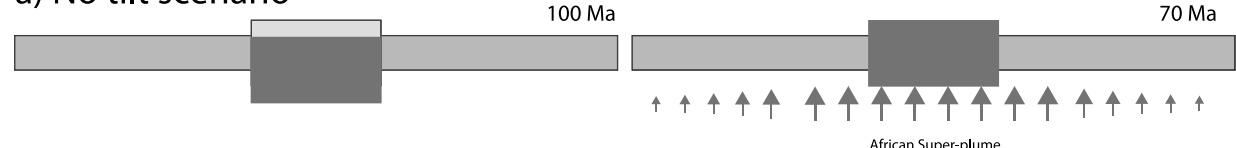

b) Tilt scenario

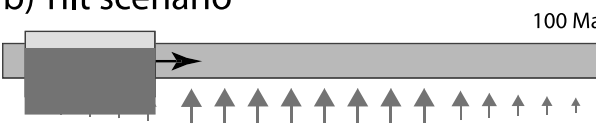

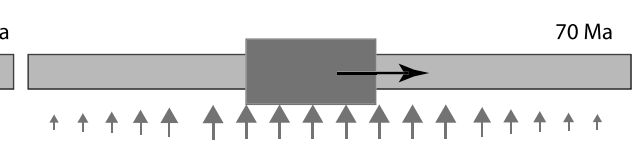

Figure 6. Schematic representation of vertical stress (arrows) applied at the base of the continental lithosphere (dark grey box) (a) in the no-tilt case and (b) in the tilt case. After $30 \mathrm{Myr}$ the two scenarios are identical with a constant (and uniform) applied stress.

and the other one in which it evolves from a gentle tilt to the West to the same uniform spatial pattern, simulating the passive eastward motion of the lithospheric plate over a fixed source of mantle upwelling (we will refer to this scenario as the "tilt case"; Figure 6b). In both cases, the stress is gradually imposed over a time period, $T$, which we vary between 10 and $30 \mathrm{Myr}$, and its final value is scaled to give rise to the same dynamic topography (of $1 \mathrm{~km}$ surface amplitude) for the density layering given in Table 1 . This value is based on estimates for the present-day anomalous topography of Southern Africa [Nyblade and Robinson, 1994]. Model parameters are given in Table 1.

\section{Model Results}

\subsection{Reference Models (Tilt and No-Tilt Cases)}

The basic results are summarized in Figures 7 and 8, where we show the evolution of the erosion rate integrated over the entire model (Figure 7), which we take as a proxy for the sedimentary flux leaving the continent into the marginal basins and snapshots of the topography over which we have draped the lithology of the surface rocks (Figures $8 \mathrm{a}$ and $8 \mathrm{~b}$ ). The model characterized by a uniform uplift (no-tilt case) shows a period of rapid erosion during the first $20 \mathrm{Myr}$ of uplift, followed by a period of relatively uniform erosion of the plateau, during which it is progressively eroded along its margins (Figure 8a). The sedimentary flux during the postuplift phase (red curve in Figure 7) is of similar amplitude to the flux predicted during the first 30 Myr such that the plateau is relatively deeply incised along its margins 90 Myr after the onset of uplift.

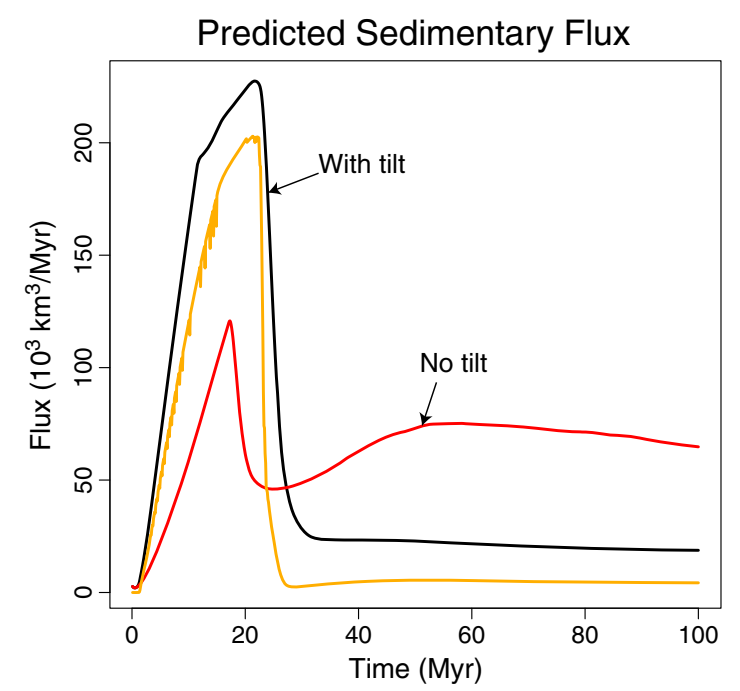

Figure 7. Predicted sedimentary flux leaving the model as a function of time as predicted by the two reference models. The orange line corresponds to the flux coming out of the left-hand side (western) boundary of the model in the tilt case.
The model characterized by a tilt of the continent (tilt case) displays a much more dramatic and rapid phase of erosion during the first 20 Myr of evolution of the model (Figure $8 b$ ), followed by a long phase of more subdued erosion (black curve in Figure 7). In both model, $T$ is equal to $30 \mathrm{Myr}$. The reason for this enhanced erosion during the period of tilt is the continental-scale organization of the drainage system toward the western margin of the model (Figure $8 \mathrm{~b}$, first panel), which results in an amplification of the erosion rate by increased drainage area. In the no-tilt case, this reorganization of the drainage system does not take place and the erosion is concentrated along the margins of the plateau (Figure 8a) during both the uplift stage and the remaining part of the model run.

The total volume of rock removed from the landscape is $5.53 \times 10^{6} \mathrm{~km}^{3}$ in the tilt case, compared to $6.45 \times 10^{6} \mathrm{~km}^{3}$ for the no-tilt case. Interestingly, the final mean topography is 
a) No tilt

$\mathrm{t}=15 \mathrm{Myr}$

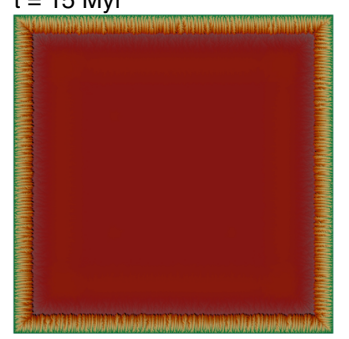

$\mathrm{t}=30 \mathrm{Myr}$
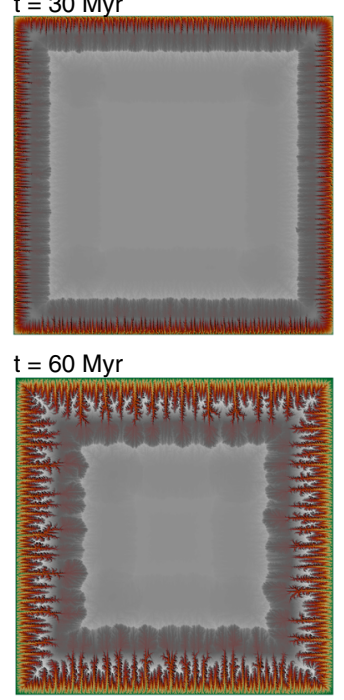

$\mathrm{t}=90 \mathrm{Myr}$

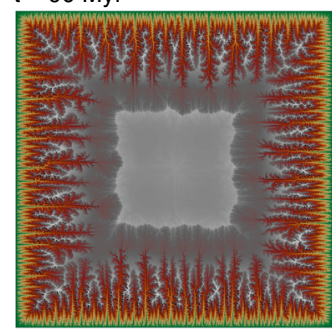

b) Tilt

$\mathrm{t}=15 \mathrm{Myr}$

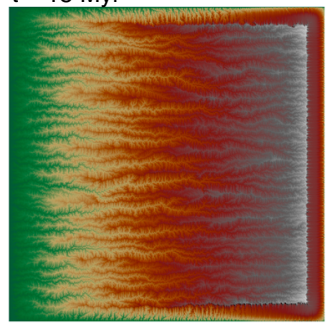

$\mathrm{t}=30 \mathrm{Myr}$

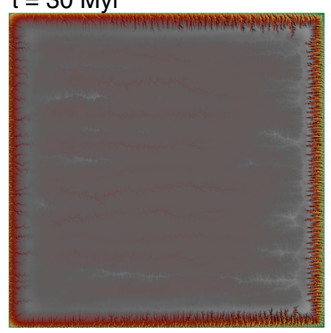

$\mathrm{t}=60 \mathrm{Myr}$

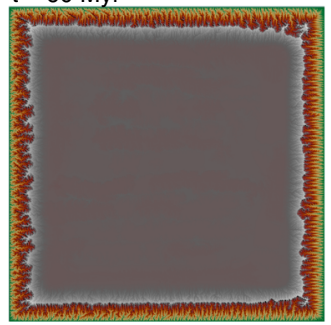

$\mathrm{t}=90 \mathrm{Myr}$
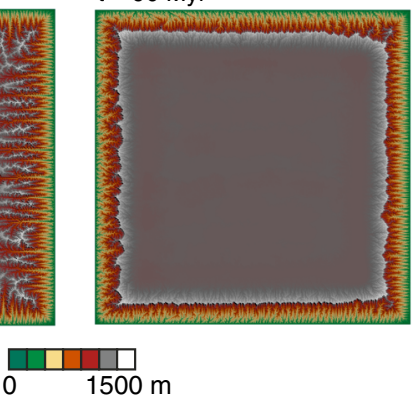

Figure 8. Evolution of computed surface topography as a function of time for the two scenarios, (a) no tilt case and (b) tilt case.

sedimentary and volcanic rocks and that their thickness can

sedimentary and volcanic rocks and that their thickness can be obtained from the total volume of sediment stored in the margins. Note, however, that our model does not include the effect of chemical weathering and mass loss, which must be taken into account when estimating total erosion from sedimentary volumes.

The model predicts that most of the sediment eroded during the tilt phase exits the plateau along its (left) western boundary (orange line in Figure 7). If our scenario is correct, we can argue that most of the sediment corresponding to the Late Cretaceous erosion pulse is stored along the South African and Namibian Atlantic margin. A recent study [Rouby et al., 2009] of the volume of sediments in the Orange system alone gives estimates of $0.75-1.5 \times 10^{6} \mathrm{~km}^{3}$ for the period 100-60 Ma. Assuming that half of the volume of sediment removed has been lost to chemical weathering [Gaillardet et al., 1999; Larsen et al., 2014] leads to an approximate thickness of $1.5-3 \mathrm{~km}$ uniformly eroded over the $10^{6} \mathrm{~km}^{2}$ present-day Orange River catchment. Similarly, if we use our estimate of 1.9 to $2.3 \times 10^{6} \mathrm{~km}^{3}$ for the whole western margin of the plateau, we end up with a total denudation estimate of $1.2-1.5 \mathrm{~km}$ distributed over a slightly larger area $\left(1.5 \times 10^{6} \mathrm{~km}^{2}\right)$ than 
a) No tilt

Total erosion

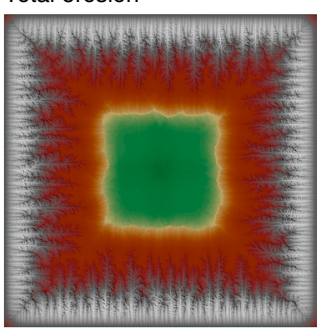

Topography

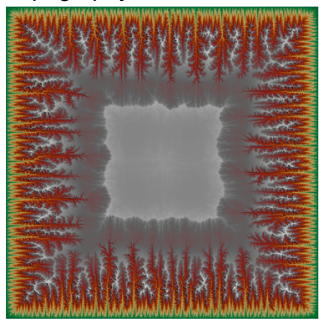

Lithology

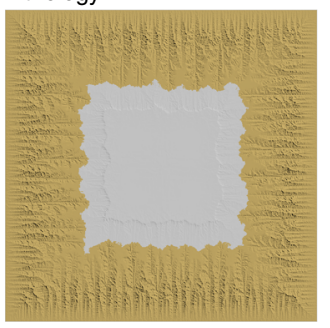

b) Tilt

Total erosion

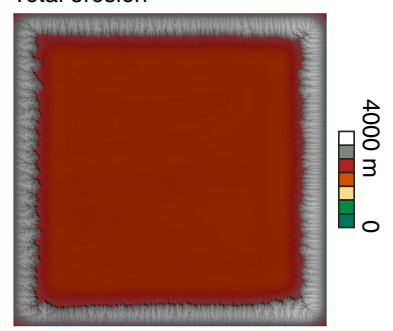

Topography

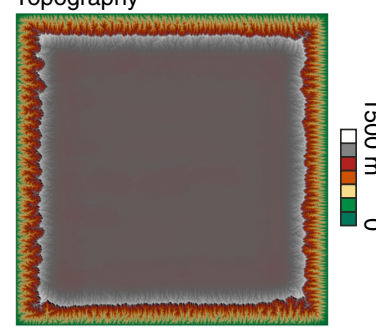

Lithology

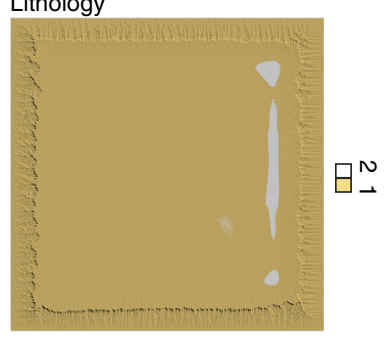

Figure 9. Computed total erosion (top panels), topography (middle panels) and surface lithologies (bottom panels) at the end of $100 \mathrm{Myr}$ long model runs, for the two scenarios (a) no tilt case and (b) tilt case. The two colors in the bottom panels correspond to the two lithologies (yellow corresponds to the harder underlying lithology and white to the softer overlying lithology).

the Orange catchment alone (Figure 4); this estimate increases to $2.4-3 \mathrm{~km}$ taking into account the amount lost to chemical weathering. These figures should, however, be regarded as upper bound estimates that need to be reconciled with the partial preservation of 90-85 Ma old kimberlite pipes in Botswana and South Africa, suggesting that a maximum of 1 to $1.5 \mathrm{~km}$ of rocks was eroded since their emplacement [Hanson et al., 2009].

\subsection{Effect of the Duration of the Active Uplift Phase, $T$}

The imposed duration of the phase of active uplift plays a secondary role in the sedimentary flux response of the system (Figure 10a), as long as it is long enough to remove most of the soft material from the top of the plateau ( $T=20$ or $30 \mathrm{Myr}$ ). As $T$ decreases, the rate of uplift of the plateau increases (as we assume that the final amplitude of the imposed dynamic topography is the same in all cases, $1 \mathrm{~km}$ ), larger slopes are reached earlier during the phase of uplift, which increases the local erosion rate and thus the sedimentary flux. However, if $T$ is too small, a nonnegligible proportion of the soft layer stays on top of the plateau at the end of the uplift phase and is eroded away in the subsequent stages of model evolution. In this situation ( $T=10 \mathrm{Myr}$ ), the first phase of rapid erosion is very short (it lasts $10 \mathrm{Myr}$ ), but the sedimentary flux remains relatively high in the second, stable phase of evolution of the plateau.

\subsection{Effect of the Lithological Contrast}

Introducing $r$ as the ratio between the value of $K$ (the fluvial erosion parameter) for the upper soft layer and that of the underlying, more resistance rocks, we note that the size of the early sedimentary pulse increases with the value of $r$ (Figure 10b). For high value of $r(=30)$ corresponding to a large lithological contrast in erodibility, the initial sediment pulse is amplified in comparison to the reference situation described above and corresponding to $r=10$. For $r=30$, the initial pulse is in fact made of two separate events, the first corresponding to the complete removal of the soft cover, the second to the incision of the underlying harder lithology while the plateau is still inclined.

When $r$ is decreased from its reference value of 10 to 3 , the initial pulse is proportionally smaller such that the soft layer is not entirely removed during the phase of active uplift and tilting of the plateau, and its erosion continues for most of the model duration. When no lithological contrast exists $(r=1)$, there is no pulse. This clearly demonstrates that to create a rapid pulse of sedimentation and thus denudation on top of the plateau, one needs to call upon a mechanism to enhance erosion during uplift of the plateau (the tilt) and a strong lithological contrast to slow it down after uplift.

\subsection{Effect of Flexure}

Although the isostatic part of the model is essential to correctly predict the effect of erosion on the amplitude of the dynamic topography, as explained earlier, the effective elastic plate thickness, $T_{e}$, used 
a) Effect of uplift duration

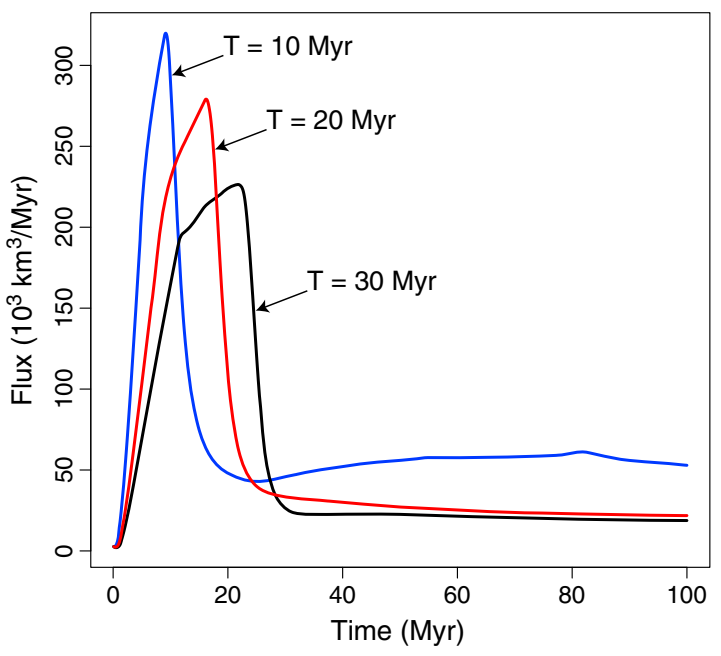

c) Effect of effective elastic thickness

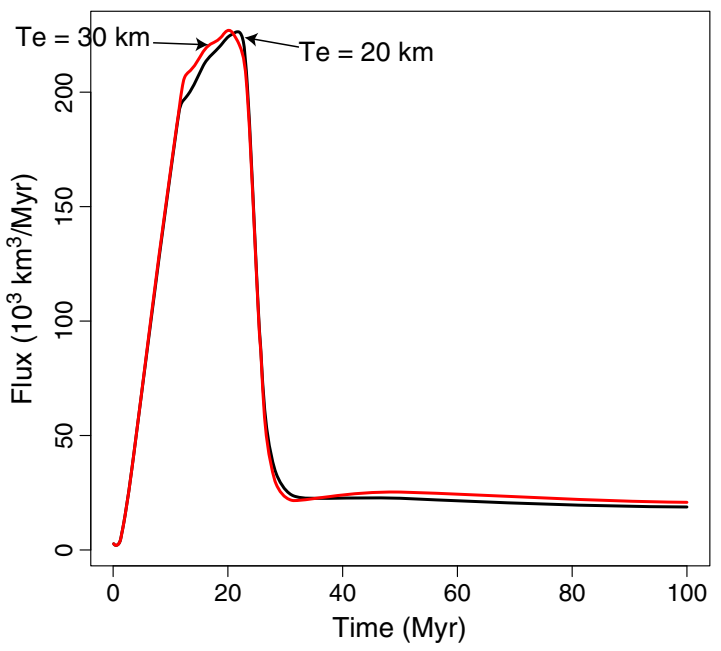

b) Effect of lithological contrast

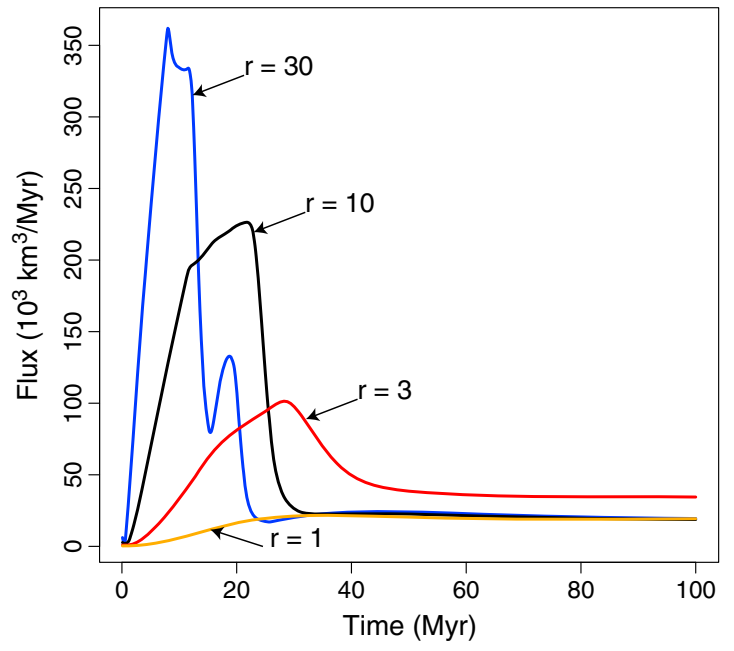

d) Effect of local drainage minima

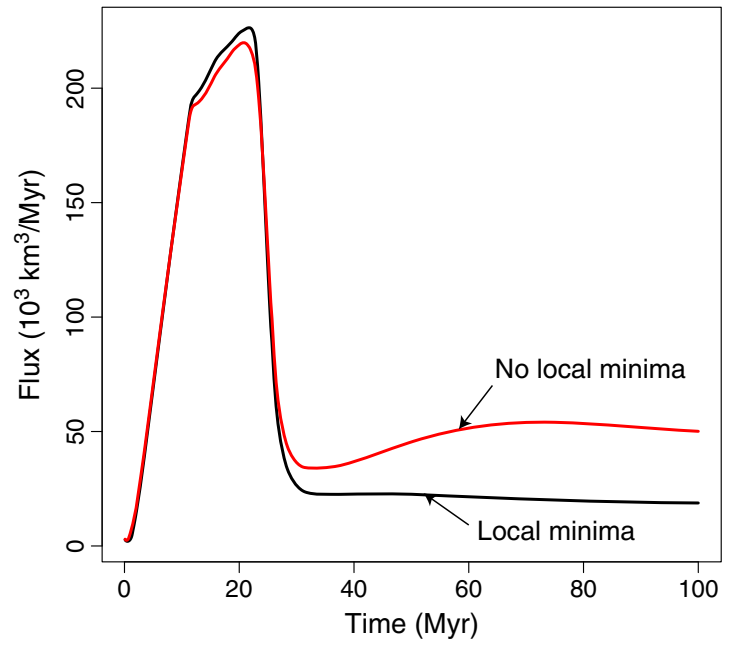

Figure 10. Sedimentary flux leaving the model as a function of time for several experiments highlighting the importance of (a) the duration of uplift ( $T$ ), (b) the assumed lithological contrast $(r)$, (c) the effective elastic plate thickness ( Te) used in the flexural isostatic calculations, and (d) the removal of local drainage minima.

to compute the flexural isostatic response does not influence the solution of the model (Figure 10c). Flexure is responsible for the relative uplift of the edges of the plateau in response to the erosion of the coastal regions. The uplifted edges of the plateau form a local drainage divide that prevents its erosion by fluvial incision because it is proportional to drainage area (equation (1)) and is thus minimal at drainage divide.

\subsection{Effect of Endoreic Versus Connected Flow}

The slow erosion of the plateau during the second (postuplift) stage of its evolution is amplified (Figure 10d) in models where drainage toward the interior of the plateau is allowed (formation of endoreic systems), in comparison with those in which all parts of the drainage system are forced to be connected to sea level (the boundary or "base level" of the model). In our code, this is done by computing the geometry of "lakes" that form around local topographic minima and their spill over points. In natural systems, the situation must lie in between these two extreme drainage geometries, depending on the long-term balance between precipitation and evaporation. However, the effect of endoreic drainage is relatively weak on the existence and amplitude of the sedimentation pulse during the tilt phase. 
a) Effect of varying exponent $n$

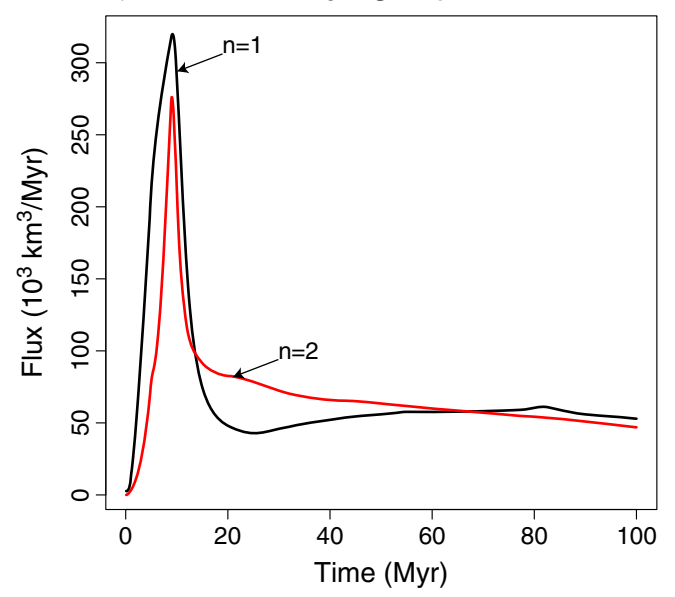

b) Changing the climate

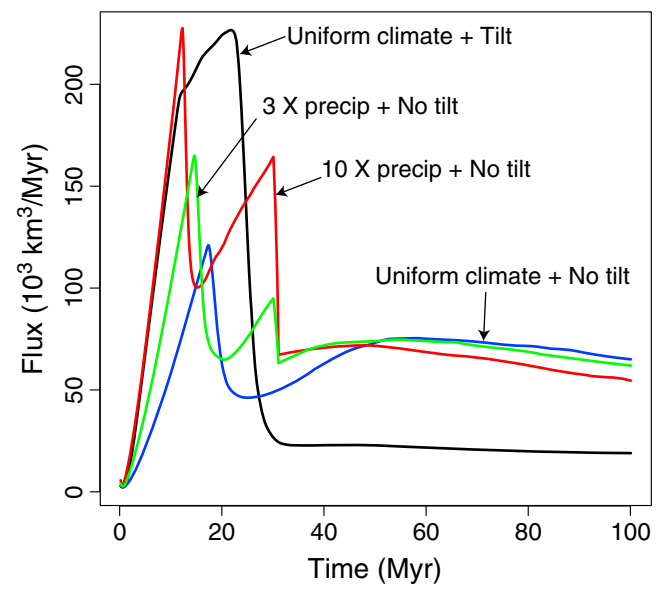

Figure 11. Sedimentary flux leaving the model as a function of time for other experiments highlighting the importance of (a) the $n$ exponent in the erosion law and (b) enhanced precipitations.

\subsection{Effect of $\boldsymbol{n}$ Exponent}

Changing the value of the exponent $n$ has relatively little effect on the flux evolution with time, as shown in Figure 11a where we reproduce the tilt experiment (with a tilt duration of $10 \mathrm{Myr}$ ) using a value of $n=2$. The solution is very similar in amplitude and duration, except that the pulse in sedimentary flux is sharper for $n=2$ in comparison to the reference situation where $n=1$.

\subsection{Effect of Climate}

We investigated the effect of replacing the continental tilt by a period of enhanced precipitation corresponding to a transition from semiarid to humid conditions. We run the model under the assumption of a uniform uplift (no tilt) over the first 30 Myr of the model, but arbitrarily multiplying the precipitation by a factor 3 and, in a second experiment, by a factor 10 during the uplift period (first 30 Myr of the model run). The results (Figure 10b) show that an extreme increase in mean precipitation rate (tenfold increase) is capable of generating a major pulse in the sediment flux through the model boundaries. A more realistic threefold increase in precipitation rate produced a noticeable but much reduced pulse in sedimentation. The model therefore demonstrates that the Late Cretaceous pulse in sedimentary flux into the Southern African margins could have been created by climate change. Although large, the magnitude of the change in precipitation rate that is required could have taken place during the change from semiarid to very humid conditions at $80 \mathrm{Ma}$ that is supported by our data compilation. Today's mean annual precipitation in arid regions is typically $<200 \mathrm{~mm} / \mathrm{yr}$, whereas very humid conditions are characterized by a mean annual precipitation $>3000 \mathrm{~mm} / \mathrm{yr}$. However, to produce the E-W asymmetry in the sedimentary flux would have required a progressive transition in climate from east to west and a greater intensification of the precipitations in the west, which is not supported by available evidence on the paleoclimate of the region.

\section{Discussion}

As discussed in section 1, several contradictory scenarios have been proposed for the uplift of the Southern African Plateau, differing mostly by the timing of the major pulse of uplift, and, consequently, by the nature of the mechanism invoked to explain its present-day anomalous topography. These scenarios include rifting along the margins, mantle upwelling, and lithospheric delamination or onset of extension in the East African Rift system. The sedimentary flux compilation that we presented here indicates a major phase of rapid denudation between 90 and $70 \mathrm{Ma}$ that is likely to be related to a major phase of uplift of the plateau. This episode coincides with the migration of the African continent over the superplume indicating a causal relationship between uplift and flow in the underlying mantle. This is further supported by the diachronism between uplift in the east and west, and the correlation with kimberlite eruptions. 
How much of the total present-day anomalous topography of the plateau can be accounted for by this phase of uplift is, however, difficult to constrain. The postrift (i.e., $130 \mathrm{Ma}$ ) phase of escarpment retreat, supported by fission track data [van der Beek et al., 2002], is also consistent with the sedimentary flux data that we have compiled, but only along the Indian Ocean margin. Along the western margin of the plateau, denudation took place around 80-60 Ma, as supported by fission track data [Gallagher and Brown, 1999] and our sedimentary flux data, and is therefore in agreement with the mechanism we propose here for the uplift of the plateau. A recent contribution to plateau uplift is not observed in the sedimentary flux data. However, as recently pointed out by Rowley [2013], it is possible that uplift of Southern Africa is sufficiently recent that the continent's interior has not had the time to respond to the uplift and the subsequent relative drop in base level. Consequently, this recent phase of uplift would not have been recorded yet in the sedimentary record.

Recent denudation rates estimated from cosmogenic isotopes from dolerites of the Karoo Basin [Decker et al., 2013] confirm that present-day erosion rates on the Southern African Plateau and its margins are very low (less than a few meters per million years), and suggest that erosion of the plateau surface is weathering limited, a situation that may have existed since the end of the Cretaceous. Apatite U-Th/He ages from samples across the southeastern margin of the plateau [Flowers and Schoene, 2010] demonstrate that most of the erosion on top of the plateau and along its escarpment took place during the Late Cretaceous, and that little or no erosion has taken place since. Such observations are in good agreement with our sedimentary flux data and call for a mechanism that can explain not only the major pulse of erosion 80-60 Ma but also the subsequent abrupt decrease in erosion rate to values that have characterized the area for most of the Cenozoic. The tilt of the continent, as it rises over the African superplume, is one such mechanism and, to our knowledge, the only one that can account for both the Late Cretaceous erosional pulse and the Cenozoic lowsedimentation rate.

Some authors [see Decker et al., 2013] postulated that the cooling climate of the Cenozoic was responsible for the decrease in denudation rates. We have shown here that variations in precipitation rate could indeed explain the erosional history of the plateau over the past 100 Myr or so, but the diachronism observed in the sedimentary flux data between the eastern and western margins of the plateau cannot be easily accounted for by a climatic control on erosion rate. The observations we have collected here on the paleoclimate of Southern Africa show, in fact, that the increase in precipitation rates in the time interval 80-60 Ma is focused mostly along the margins of the plateau, suggesting that it may be an orographic effect associated with the rise of the plateau and thus a consequence, rather than the cause of the uplift and erosion of the plateau.

The mechanism we propose here for the rapid unroofing of the plateau is based on the argument that tilting of the continent caused a major drainage reorganization to the west. Present-day drainage over the plateau is strongly asymmetrical and controlled by the Orange River and its tributaries, which flows from east to west across most of the plateau area. This asymmetry of the drainage system could date back to Late Cretaceous times [Rouby et al., 2009] and is certainly much older than any other African river network, such as the Nile [Macgregor, 2012] or the Niger.

Although the scenario we propose for the geomorphic evolution of the Southern African Plateau is the result of a combination of factors - the migration of the continent over a fixed source of mantle upwelling and the preexistence of a strong lithological contrast at the surface-other regions may have been subjected to a similar scenario. For example, the recent denudation of the top of the Colorado Plateau may be the result of the passage of the North American continent over a fixed source of dynamic topography [Braun et al., 2013].

\section{Conclusions}

We have presented a new compilation of data that constrains the flux of siliclastic sediments into the marginal basins surrounding the Southern African Plateau over the past 100 Myr. The data confirm that the plateau underwent a major phase of denudation in the Late Cretaceous ( 80 to $60 \mathrm{Ma}$ ) when several kilometers of rocks were eroded away from the plateau surface. The compilation also shows that, although this phase of erosion started along the eastern margin of the present-day plateau, the largest sediment accumulation is observed along its western margin, near the mouth of the present-day Orange River. The data show that for most of the Cenozoic the marginal basins were starved and, consequently, that despite its present-day high elevation, the plateau has seen little or no erosion in the past 60 Myr. 
We have proposed a mechanism that can explain the phase of rapid denudation, as well as the long period of erosional quiescence that followed. Using a surface processes model, we have demonstrated that tilting of the continent in response to its migration over a source of dynamic topography (here the African superplume) results in a continental-scale reorganization of the drainage system that strongly increases its erosional efficiency. As the continent migrates over the superplume, it becomes flat again and erosion rate rapidly decreases. This effect is further amplified by the presence of at least $1 \mathrm{~km}$ of soft Karoo sedimentary rocks that blanketed most of the plateau surface in the mid-Cretaceous. The hardness contrast between these sedimentary rocks and the underlying basement is, in part, responsible for the reduction in Cenozoic denudation rates.

We have shown the importance of the various model parameters on the evolution of the predicted sedimentary fluxes coming out of the plateau to demonstrate that our proposed mechanism is a robust consequence of the basic dependence of erosion rate on slope and drainage area. We also attempted to assess whether climate (precipitation) variability could be responsible for the observed erosional pulse. We compiled existing data on paleoprecipitations across the Southern African Plateau to show that the margins of the plateau have experienced an increase in precipitation from semiarid to very humid conditions some $80 \mathrm{Ma}$, as well as a return to semiarid conditions in the Cenozoic. We argue, however, that climate variability cannot be the main driver for the erosion pulse because it cannot explain the diachronism of the erosion and sedimentary flux along the eastern and western margins of the plateau.

\section{Acknowledgments}

The work presented in this manuscript was financed by a grant from the Agence Nationale de la Recherche (projet TopoAfrica) and supported by the Canadian Institute for Advanced Research. We would like to thank Olivier Dauteuil (Rennes) et Delphine Rouby (Toulouse) for helpful discussions.

\section{References}

Bamford, M. K. (2000), Cenozoic macro-plants, in The Cenozoic of Southern Africa, edited by T. C. Partridge and R. R. Maud, pp. 351-356, Oxford Univ. Press, Oxford, U. K.

Bamford, M. K., and M. C. J. de Wit (1993), Taxonomic description of fossil wood from Cainozoic Sak River terraces, near Brandvlei, Bushmanland, South Africa, Palaeontol. Afr., 30, 71-80.

Bamford, M. K., and I. R. Stevenson (2002), A submerged Late Cretaceous podocarpaceous forest, west coast, South Africa, S. Afr. J. Sci., 98 , 181-185.

Bell, D. R., M. D. Schmitz, and P. E. Janney (2003), Mesozoic thermal evolution of the southern African mantle lithosphere, Lithos, 71(2-4), 273-287, doi:10.1016/S0024-4937(03)00117-8.

Bonnefille, R. (2010), Cenozoic vegetation, climate changes and hominid evolution in tropical Africa, Global Planet. Change, $72,390-411$.

Braun, J., and S. D. Willett (2012), A very efficient $O(n)$, implicit and parallel method to solve the stream power equation governing fluvial incision and landscape evolution, Geomorphology, 180-181, 170-179, doi:10.1016/j.geomorph.2012.10.008.

Braun, J., X. Robert, and T. Simon-Labric (2013), Eroding dynamic topography, Geophys. Res. Lett., 40, 1494-1499, doi:10.1002/grl.50310.

Brown, L. F. J., J. M. Benson, G. J. Brink, S. Doherty, A. Jollands, E. H. A. Jungslager, J. H. G. Keenan, A. Muntingh, and N. J. S. van Wyk (1995), Sequence Stratigraphy in Offshore South African Divergent Basins: An Atlas on Exploration for Cretaceous Lowstand Traps by Soekor (Pty) Ltd, Studies in Geology, vol. 41, 184 pp., American Association of Petroleum Geologists, Tulsa, Okla.

Brown, R. W., D. J. Rust, M. A. Summerfield, A. J. Gleadow, and M. C. De Wit (1990), An Early Cretaceous phase of accelerated erosion on the south-western margin of Africa: Evidence from apatite fission track analysis and the offshore sedimentary record, Int. J. Radiat. Appl. Instrum. Part D Nucl. Tracks Radiat. Meas., 17(3), 339-350.

Brown, R. W., M. A. Summerfield, and A. J. Gleadow (2002), Denudational history along a transect across the Drakensberg Escarpment of southern Africa derived from apatite fission track thermochronology, J. Geophys. Res., 107(B12), 2350, doi:10.1029/2001JB000745.

Burke, K. (1996), The African plate, S. Afr. J. Geol., 99(4), 339-409.

Catuneanu, O., P. J. Hancox, and B. S. Rubidge (1998), Reciprocal flexural behavior and contrasting stratigraphies: A new basin development model for the Karoo retroarc foreland system, South Africa, Basin Res., 10, 417-439.

Cooper, M. R. (1988), A new bivalve from the late Jurassic of Zimbabwe, S. Afr. J. Geol., 91, 321-325.

Decker, J. E., S. Niedermann, and M. J. De Wit (2013), Climatically influenced denudation rates of the souther African plateau: Clues to solving a geomorphic paradox, Geomorphology, 190, 48-60, doi:10.1016/j.geomorph.2013.02.007.

Dessert, C., B. Dupré, J. Gaillardet, L. M. François, and C. J. Allègre (2003), Basalt weathering laws and the impact of basalt weathering on the global carbon cycle, Chem. Geol., 202, 257-273.

de Vera, J., P. Granado, and K. McClay (2010), Structural evolution of the Orange Basin gravity-driven systems, offshore Namibia, Mar. Pet. Geol., 27, 223-227.

de Villiers, S. E. (1999), Palaeobotanical implications arising from palynological studies of Eocene sediments from the continental shelf, Northern Cape Province, South Africa, in Actes du 4ème Symposium de Palynologie africaine, Sousse, Tunisie, Geo-Eco-Trop, Numéro Spécial, edited by Geo-Eco-Trop, pp. 129-140, Brusells, Belgium.

Flowers, R. M., and B. Schoene (2010), (U-Th)/He thermochronology constraints on unroofing of the eastern Kaapval craton and significance for uplift of the souther African plateau, Geology, 38, 827-830.

Gaillardet, J., B. Dupre, P. Louvat, and C. Allegre (1999), Global silicate weathering and $\mathrm{CO}_{2}$ consumption rates deduced from the chemistry of large rivers, Chem. Geol., 159, 3-30.

Gallagher, K., and R. Brown (1999), Denudation and uplift at passive margins: The record on the Atlantic Margin of Southern Africa [and Discussion], Philos. Trans. Math. Phys. Eng. Sci., 357(1753), 835-859.

Gomez, B., X. Martinez-Delclos, M. Bamford, and M. Philippe (2002), Taphonomy and palaeoecology of plant remains from the oldest African Early Cretaceous amber locality, Lethaia, 35, 300-308.

Guillocheau, F., D. Rouby, C. Robin, C. Helm, N. Rolland, L. Carlier, C. de Veslud, and J. Braun (2012), Quantification and causes of the terrigeneous sediment budget at the scale of a continental margin: A new method applied to the Namibia-South Africa margin, Basin Res., 24, 3-30. 
Gurnis, M., J. Mitrovica, J. Ritsema, and H. van Heijst (2000), Constraining mantle density structure using geological evidence of surface uplift rates: The case of the African superplume, Geochem. Geophys. Geosyst., 1(7), 1020, doi:10.1029/1999GC000035.

Hanson, E. K., J. M. Moore, E. M. Bordy, J. S. Marsh, G. Howarth, and J. V. A. Robey (2009), Cretaceous erosion in central South Africa: Evidence from upper-crustal xenoliths in kimberlite diatremes, S. Afr. J. Geol., 112, 125-140.

Haq, B. U., J. Hardenbol, and P. R. Vail (1987), Chronology of fluctuating sea levels since the Triassic, Science, 235, 1156-1167.

Howard, A. D., and G. Kerby (1983), Channel changes in badlands, Geol. Soc. Am. Bull., 94(6), 739-752.

Jelsma, H. A., M. J. de Wit, C. Thiart, P. H. G. M. Dirks, G. Viola, I. J. Basson, and E. Anckar (2004), Preferential distribution along transcontinental corridors of kimberlites and related rocks of Southern Africa, S. Afr. J. Geol., 107, 301-324.

Jelsma, H. A., W. Barnett, S. Richards, and G. Lister (2009), Tectonic setting of kimberlites, Lithos, 112S, 155-165.

Jerram, D., N. Mountney, F. Holzförster, and H. Stollhofen (1999), Internal stratigraphic relationships in the Etendeka Group in the Huab Basin, NW Namibia: Understanding the onset of flood volcanism, J. Geodyn., 28, 393-418.

Johnson, M. R., C. J. van Vuuren, W. F. Hegenberger, R. E. Key, and U. Shoko (1996), Stratigraphy of the Karoo Supergroup in southern Africa: An overview, J. Afr. Earth Sci., 23, 3-15.

Jourdan, F., G. Féraud, H. Bertrand, M. K. Watkeys, and P. R. Renne (2008), The ${ }^{40} \mathrm{Ar} /{ }^{39} \mathrm{Ar}$ ages of the sill complex of the Karoo large igneous province: Implications for the Pliensbachian-Toarcian climate change, Geochem. Geophys. Geosyst., 9, Q06009, doi:10.1029/2008GC001994.

Lague, D., and N. Hovius (2005), Discharge, discharge variability, and the bedrock channel profile, J. Geophys. Res., 110, F04006, doi:10.1029/ 2004JF000259.

Larsen, I. J., D. R. Montgomery, and H. M. Greenberg (2014), The contribution of mountains to global denudation, Geology, 42(6), 527-530, doi:10.1130/G35136.1.

Macgregor, D. S. (2012), The development of the Nile drainage system: Intégration of onshore and offshore evidence, Pet. Geosci., 18, 417-431, doi:10.1144/petgeo2011-074.

Marsh, J. S., P. R. Hooper, J. Rehacek, R. A. Duncan, and A. R. Duncan (1997), Stratigraphy and age of Karoo basalts of Lesotho and implications for correlations within the Karoo igneous province, in Large Igneous Provinces: Continental, Oceanic and Planetary Flood Volcanism, Geophys. Monogr. Ser., edited by J. J. Mahoney and M. F. Coffin, pp. 247-272, AGU, Washington, D. C.

Melluso, L., C. Cucciniello, C. M. Petrone, M. Lustrino, V. Morra, M. Tiepolo, and L. Vasconcelos (2008), Petrology of Karoo volcanic rocks in the southern Lebombo monocline, Mozambique, J. Afr. Earth Sci., 52, 139-151.

Miller, K. G., M. A. Kominz, J. V. Browning, J. D. Wright, G. S. Mountain, M. E. Katz, P. J. Sugarman, B. S. Cramer, N. Christie-Blick, and S. F. Pekar (2005), The Phanerozoic record of global sea-level change, Science, 310, 1293-1298.

Nyblade, A. A., and S. Robinson (1994), The African superswell, Geophys. Res. Lett., 21(9), 765-768, doi:10.1029/94GL00631.

Nyblade, A. A., and N. H. Sleep (2003), Long lasting epeirogenic uplift from mantle plumes and the origin of the Southern African Plateau, Geochem. Geophys. Geosyst., 4(12), 1105, doi:10.1029/2003GC000573.

Partridge, T. C., and R. R. Maud (1987), Geomorphic evolution of Southern Africa since the Mesozoic, S. Afr. J. Geol., 90, 179-208.

Pickford, M., and B. Senut (1999), Geology and Palaeobiology of the Namib Desert Southwest Africa, Memoir, vol. 18, 155 pp., Geological Survey of Namibia, Windhoek, Namibia.

Posamentier, H. W., M. T. Jervey, and P. R. Vail (1988), Eustatic controls on clastic deposition. I. Conceptual framework, in Sea-Level Changes: An Integrated Approach, Special Publication, edited by C. K. Wilgus et al., pp. 109-124, Society of Economic Paleontologists and Mineralogists, Tulsa, Okla.

Posamentier, H. W., G. P. Allen, D. P. James, and M. Tesson (1992), Forced regressions in a sequence stratigraphic framework: Concepts, examples, and exploration significance, Am. Assoc. Pet. Geol. Bull., 76, 1687-1709.

Pysklywec, R., and J. X. Mitrovica (1999), The role of subduction-induced subsidence in the evolution of the Karoo Basin, J. Geol., 107, $155-164$.

Qin, X., R. D. Müller, J. Cannon, T. C. W. Landgrebe, C. Heine, R. J. Watson, and M. Turner (2012), The GPlates geological information model and markup language, Geosci. Instrum. Methods Data Syst. Discuss., 2, 365-428, doi:10.5194/gid-2-365-2012.

Rayner, R. J., M. K. Bamford, D. J. Brothers, A. S. Dippenaar-Schoeman, I. J. McKay, R. G. Oberprieler, and S. B. Waters (1997), Cretaceous fossils from the Orapa Diamond Mine, Palaeontol. Afr., 33, 55-65.

Roberts, D. L., L. Sciscio, A. I. R. Herries, L. Scott, M. K. Bamford, C. Musekiwa, and H. Tsikos (2013), Miocene fluvial systems and palynofloras at the southwestern tip of Africa: Implications for regional and global fluctuations in climate and ecosystems, Earth Sci. Rev., 124, 184-201.

Robin, C., F. Guillocheau, and J. M. Gaulier (1998), Discriminating between tectonic and eustatic controls on stratigraphic record in the Paris Basin, Terra Nova, 10, 323-329.

Rouby, D., S. Bonnet, F. Guillocheau, K. Gallagher, C. Robin, F. Biancotto, O. Dauteuil, and J. Braun (2009), Sediment supply to the Orange sedimentary system over the last 150My: An evaluation from sedimentation/denudation balance, Mar. Pet. Geol., 26(6), 782-794, doi:10.1016/j.marpetgeo.2008.08.004

Rowley, D. B. (2013), Sea level: Earth's dominant elevation: Implications for duration and magnitudes of sea level variations, J. Geol., 21, 445-454, doi:10.1086/671392.

Salman, G., and I. Abdula (1995), Development of the Mozambique and Ruvuma sedimentary basins, offshore Mozambique, Sediment. Geol., 96, 7-41.

Sandersen, A. (2006), A Palynological Investigation of the Offshore Cretaceous Sequence on the South-West Coast of South Africa, 566 pp., Faculty of Science, Univ. of Witwatersrand, Johannesburg, South Africa.

Scholtz, A. (1985a), The palynology of the upper lacustrine sediments of the Arnot Pipe, Banke, Namaqualand, Ann. S. Afr. Mus., 95, 1-109.

Scholtz, A. (1985b), The palynology of the upper lacustrine sediments of the Arnot Pipe, Namaqualand-A summary, Ann. Geol. Surv. S. Afr., 19, 85-87.

Ségalen, L., M. Renard, J. A. Lee-Thorp, L. Emmanuel, L. Le Callonnec, M. de Rafélis, B. Senut, M. Pickford, and J. L. Melice (2006), Neogene climate change and emergence of C4 grasses in the Namib, southwestern Africa, as reflected in ratite 13C and 180, Earth Planet. Sci. Lett., $244,725-734$.

Senut, B., and M. Pickford (1995), Fossil eggs and Cenozoic continental biostratigraphy of Namibia, Palaeontol. Afr., 32, 33-37.

Shone, R. W., and P. W. K. Booth (2005), The Cape Basin, South Africa: A review, J. Afr. Earth Sci, 43, 196-210.

Simmons, N. A., A. M. Forte, and S. P. Grabd (2007), Thermomechanical structure and dynamics of the African superplume, Geophys. Res. Lett., 34, L02301, doi:10.1029/2006GL028009.

Smith, R. M. H. (1986), Sedimentation and paleoenvironments of Late Cretaceous crater-lake deposits in Bushmanland, South Africa, Sedimentology, 33, 369-386.

Smith, R. M. H. (1988), Palaeoenvironmental reconstruction of a Cretaceous crater-lake deposit in Bushmanland, South Africa, Palaeoecol. Afr., $19,27-41$. 
Tankard, A., H. Welsink, P. Aukes, R. Newton, and E. Stettler (2009), Tectonic evolution of the Cape and Karoo Basins of South Africa, Mar. Pet. Geol., 26, 1379-1412.

Tinker, J., M. de Wit, and R. Brown (2008), Linking source and sink: Evaluating the balance between onshore erosion and offshore sediment accumulation since Gondwana break-up, South Africa, Tectonophysics, 455, 94-103.

Torsvik, T. H., and L. R. M. Cocks (2013), Gondwana from top to base in space and time, Gondwana Res., 24, 999-1030.

Torsvik, T. H., K. Burke, B. Steinberger, S. Webb, and L. D. Ashwal (2010), Diamonds sampled by plumes from the core-mantle boundary, Nature, 466, 352-355, doi:10.1038/nature09216.

Tyson, P. D., and T. S. Partridge (2000), Evolution of Cenozoic climates, in The Cenozoic of Southern Africa, edited by T. C. Partridge and R. R. Maud, pp. 371-387, Oxford Univ. Press, Oxford.

Uenzelmann-Neben, G., P. Schlüter, and E. Weigelt (2007), Cenozoic oceanic circulation within the South African gateway: Indications from seismic stratigraphy, S. Afr. J. Geol., 110, 275-294.

van der Beek, P., M. Summerfield, J. Braun, R.W. Brown, and A. Fleming (2002), Modeling postbreakup landscape development and denudational history across the southeast African (Drakensberg Escarpment) margin, J. Geophys. Res., 107(B12), 2351, doi:10.1029/2001JB000744.

Wanke, A., H. Stollhofen, I. G. Stanistreet, and V. Lorenz (2000), Karoo unconformities in NW-Namibia and their tectonic implications, Commun. Geol. Surv. Namibia, 12, 259-268.

Whipple, K. X. (2004), Bedrock rivers and the geomorphology of active orogens, Annu. Rev. Earth Planet. Sci., 32(1), 151-185, doi:10.1146/ annurev.earth.32.101802.120356.

Whipple, K. X., and G. E. Tucker (1999), Dynamics of the stream-power river incision model: Implications for height limits of mountain ranges, landscape response timescales, and research needs, J. Geophys. Res., 104(B8), 17,661-17,674, doi:10.1029/1999JB900120. 